\title{
Butanol production in acetone-butanol-ethanol fermentation with in situ product recovery by adsorption
}

Chuang Xue ${ }^{\mathrm{a}, \mathrm{b},+}$, Fangfang $\mathrm{Liu}^{\mathrm{b},+}$, Mengmeng Xub ${ }^{\mathrm{b}}$, I-Ching Tang ${ }^{\mathrm{c}}$, Jingbo Zhao ${ }^{\mathrm{b}}$, Fengwu Bai ${ }^{\mathrm{a}}$, Shang-Tian Yang ${ }^{\mathrm{b}, *}$

${ }^{\mathrm{a}}$ Department of Life Science and Biotechnology, Dalian University of Technology, Dalian 116024, China

${ }^{\mathrm{b}}$ Department of Chemical and Biomolecular Engineering, The Ohio State University, 151 West Woodruff Avenue, Columbus, Ohio 43210, USA

'Bioprocessing Innovative Company, 4734 Bridle Path Court., Dublin, Ohio 43017, USA

'These two authors made equal contribution

*Corresponding author: Phone: 1-614-2926611; Fax: 1-614-2923769; email: yang.15@ osu.edu

Submitted to Bioresource Technology 


\section{Abstract}

2 Activated carbon Norit ROW 0.8, zeolite CBV901, and polymeric resins Dowex Optipore

3 L-493 and SD-2 with high specific loadings and partition coefficients were studied for $n$-butanol

4 adsorption. Adsorption isotherms were found to follow Langmiur model, which can be used to

5 estimate the amount of butanol adsorbed in acetone-butanol-ethanol (ABE) fermentation. In

6 serum-bottle fermentation with in situ adsorption, activated carbon showed the best performance

7 with $21.9 \mathrm{~g} / \mathrm{L}$ of butanol production. When operated in a fermentor, free- and immobilized-cell

8 fermentations with adsorption produced $31.6 \mathrm{~g} / \mathrm{L}$ and $54.6 \mathrm{~g} / \mathrm{L}$ butanol with productivities of 0.30

$9 \mathrm{~g} / \mathrm{L} \cdot \mathrm{h}$ and $0.45 \mathrm{~g} / \mathrm{L} \cdot \mathrm{h}$, respectively. Thermal desorption produced a condensate containing $\sim 167$

$10 \mathrm{~g} / \mathrm{L}$ butanol, which resulted in a highly concentrated butanol solution of $\sim 640 \mathrm{~g} / \mathrm{L}$ after

11 spontaneous phase separation. This in situ product recovery process with activated carbon is

12 energy efficient and can be easily integrated with ABE fermentation for $n$-butanol production.

14 Keywords: Acetone-butanol-ethanol fermentation; Activated carbon; Adsorption; Butanol; in 15 situ product recovery 


\section{1. Introduction}

2 Due to concerns about depletion of crude oils and escalating prices of petroleum-derived

3 products, biobutanol has attracted attention as a liquid transportation fuel (Dürre, P., 1998; Wang

4 et al., 2014; Xue et al., 2013a). However, due to severe product inhibition caused by butanol,

5 conventional acetone-butanol-ethanol (ABE) fermentation is limited by low product titer, yield,

6 and productivity (Kumar and Gayen, 2011), resulting in intensive energy consumption for

7 product recovery by distillation (Abdehagh et al., 2014; Vane 2008; Xue et al., 2014a). Although

8 intensive efforts have been made on improving butanol tolerance and production by

9 solventogenic clostridia through adaptation, mutagenesis and metabolic engineering (Lee et al.,

10 2008; Xu et al., 2015; Yang and Zhao, 2013), 2\% (w/v) of butanol production is still a bottleneck

11 in the development of ABE fermentation (Zhao et al., 2013). Fermentation with in situ product

12 recovery (ISPR) can alleviate product inhibition and thus improve conversion and productivity

13 (Staggs and Nielsen, 2015; Xue et al., 2014a; Yang and Lu, 2013). Several online integrated

14 butanol recovery methods, including adsorption (Nielsen and Prather, 2009; Qureshi et al., 2005;

15 Wiehn et al., 2014; Yang et al., 1994), liquid-liquid extraction (Roffler et al. 1987), pervaporation

16 (Matsumura et al., 1988; Xue et al., 2014b) and gas stripping (Lu et al., 2013; Xue et al., 2012;

$172013 b ; 2014 c$ ) have been investigated. Among them, adsorption requires less energy, is easier to

18 operate (Agueda et al., 2013; Oudshoorn et al., 2009b), and has been demonstrated as an

19 effective process for separating butanol and reducing its inhibition in ABE fermentation (Liu et

20 al., 2014; Yang and Tsao, 1995).

21 Butanol recovery from dilute solution by adsorption is usually carried out in two steps:

22 adsorption followed by desorption to obtain a concentrated butanol solution with adsorbent

23 regeneration (Agueda et al., 2013; Vane, 2008). Three types of adsorbents have been widely 
1 studied for butanol adsorption: activated carbon ( $\mathrm{AC})$, zeolite $\left(\mathrm{SiO}_{2} / \mathrm{Al}_{2} \mathrm{O}_{3}\right)$, and polymeric

2 (typically ion-exchange) resins (Abdehagh et al., 2015; Liu et al., 2014; Nielsen and Prather,

3 2009; Oudshoorn et al., 2009a; Qureshi et al., 2005). In general, adsorbents should have a high

4 butanol adsorption capacity, affinity, and selectivity, and be inexpensive and easy to be

5 regenerated for reuse. Although some zeolites and silicalite could adsorb almost all butanol from

6 a dilute solution of less than $10 \mathrm{~g} / \mathrm{L}$ and be thermally regenerated to produce a butanol solution

7 of $>80 \%$ (w/v) (Milestone and Bibby, 1981; Saravanan et al., 2010), their biocompatibility for in

8 situ butanol recovery during fermentation has not been studied. Meanwhile, a recent study

9 showed that activated carbon F-400 was the best butanol adsorbent with the highest adsorption

10 capacity and fastest adsorption rate among ACs and zeolites tested (Abdehagh et al., 2013).

11 However, its application in ISPR for butanol production has not been demonstrated. To date,

12 most of prior studies of ISPR by adsorption focused on polymeric resins, which are relatively

13 expensive and have only moderate butanol adsorption capacity and selectivity (Liu et al., 2014;

14 Nielsen and Prather, 2009; Nielsen et al., 2010; Wiehn et al., 2014; Yang et al., 1994), which

15 have limited their commercial applications.

16 The goal of this study was to investigate and demonstrate the feasibility of in situ adsorption

17 for high-titer butanol production in fed-batch fermentation with Clostridium acetobutylicum

18 JB200 (Yang and Zhao, 2013). We first screened a variety of commercial adsorbents, including

19 AC, ion exchange resins and zeolites, for their ability to adsorb n-butanol from model solutions.

20 Promising adsorbents were then evaluated for their adsorption isotherms and uses in ISPR for

21 butanol production in $\mathrm{ABE}$ fermentation with cells immobilized in a fibrous bed bioreactor ( $\mathrm{Du}$

22 et al., 2015). For the first time, our results demonstrate that activated carbon Norit ROW 0.8, a

23 relatively inexpensive adsorbent, is biocompatible and effective for in situ butanol recovery for 
1 high-titer butanol production in ABE fermentation.

\section{2. Materials and Methods}

\section{$3 \quad 2.1$ Screening adsorbents for butanol adsorption}

4 Nine different adsorbents (activated carbon Norit ROW 0.8, ion exchange resins Amberlite 5 IRA-900, Amberlite XAD-4, Diaion HP-2MG, Diaion HP-20, Dowex Optipore L-493, Dowex

6 Optipore SD-2, and zeolites CBV901 and CBV28014) representing different types were selected

7 based on literature data (Abdehagh et al., 2013; Nielsen \& Prather, 2009; Nielsen et al., 2010;

8 Oudshoorn et al., 2009a; Qureshi et al., 2005; Saravanan et al., 2010). The zeolites were obtained

9 from Zeolyst International (Conshohocken, PA) while all other adsorbents were purchased from

10 Sigma-Aldrich (St. Louis, MO). They were tested for their ability to adsorb $n$-butanol in capped

11 tubes, each containing $25 \mathrm{~mL}$ of the model solution $(\sim 10 \mathrm{~g} / \mathrm{L}$ butanol $)$ and $1 \mathrm{~g}$ of a tested

12 adsorbent, at $37{ }^{\circ} \mathrm{C}$. The amount of butanol adsorbed per unit weight of the adsorbent or specific

13 loading $(q)$ was determined from the difference between the initial and final (equilibrium)

14 butanol concentrations, as follows:

$$
q=\left(C_{e q}-C_{o}\right) V / W
$$

16 where $V$ is the solution volume, $W$ is the mass of adsorbent, and $C_{o}$ and $C_{e q}$ are the butanol

17 concentrations in the solution at initial and equilibrium, respectively. The partition coefficient

$18\left(K_{r}\right)$, which indicates the affinity or potential of an adsorbent to take up butanol from the aqueous

19 solution, can be determined from the following equation:

$$
K_{r}={ }^{q} / C_{e q}
$$

\section{$21 \quad 2.2$ Adsorption isotherm}

22 Norit ROW 0.8, Dowex Optipore L-493 and SD-2, and CBV901 with high butanol adsorption 
1 capacity found in the screening tests were further studied for their adsorption isotherms at $37{ }^{\circ} \mathrm{C}$

2 and $60{ }^{\circ} \mathrm{C}$. Various amounts of adsorbents, ranging from $0.25 \mathrm{~g}$ to $6 \mathrm{~g}$, were added to $15 \mathrm{~mL}$ of

3 the model solution (butanol concentration: $39.6 \pm 1.8 \mathrm{~g} / \mathrm{L}$ ) and allowed to equilibrate for $24 \mathrm{~h}$

4 with agitation at $150 \mathrm{rpm}$. The adsorption isotherm for activated carbon, which was the best

5 among the four adsorbents studied, was further studied with a model solution containing $\sim 20 \mathrm{~g} / \mathrm{L}$

6 glucose, $\sim 20 \mathrm{~g} / \mathrm{L}$ acetone, $\sim 40 \mathrm{~g} / \mathrm{L}$ butanol, $\sim 4 \mathrm{~g} / \mathrm{L}$ ethanol, $\sim 10 \mathrm{~g} / \mathrm{L}$ acetic acid, and $\sim 4 \mathrm{~g} / \mathrm{L}$

7 butyric acid to evaluate butanol and acetone adsorption in the presence of glucose and acids.

\section{$8 \quad 2.3$ Adsorption dynamics in a packed column of activated carbon}

9 Continuous adsorption with $25 \mathrm{~g}$ Norit ROW 0.8 packed in a glass column (15 cm in length; 2.1

$10 \mathrm{~cm}$ in inner diameter) by feeding $10 \mathrm{~g} / \mathrm{L}$ butanol solution at $20 \mathrm{ml} / \mathrm{min}$ was studied for $\sim 90 \mathrm{~min}$.

11 Samples from the effluent were collected periodically to monitor butanol concentration until

12 complete breakthrough was confirmed. The fully loaded activated carbon was regenerated by

13 heating at $200{ }^{\circ} \mathrm{C}$ overnight, and then washed with three volumes of distill water and reused for

14 the next cycle of adsorption run. Continuous adsorption with a model solution containing $10 \mathrm{~g} / \mathrm{L}$

15 butanol, $5 \mathrm{~g} / \mathrm{L}$ acetone, $2 \mathrm{~g} / \mathrm{L}$ ethanol, $4 \mathrm{~g} / \mathrm{L}$ acetic acid and $2 \mathrm{~g} / \mathrm{L}$ butyric acid was also studied.

\section{$16 \quad 2.4$ Desorption dynamics}

17 Desorption of butanol, water and ABE mixture from activated carbon was first studied by

18 thermogravimetry. Briefly, butanol, water and ABE mixture with a ratio of 6:3:1 were first

19 adsorbed onto activated carbon for $24 \mathrm{~h}$ to reach saturation. Then, free (un-adsorbed) water and

20 solvents were removed from the 'wet' activated carbon by patting with filter paper. Butanol

21 desorption from the "loaded" activated carbon (initial weight: $30.37 \pm 0.18 \mathrm{~g}$ ) was then carried

22 out by heating at a gradually increased temperature $\left(10{ }^{\circ} \mathrm{C} / \mathrm{min}\right)$, from $25^{\circ} \mathrm{C}$ to $250{ }^{\circ} \mathrm{C}$, until

23 reaching a constant weight. A two-step heating process for butanol desorption was then studied. 
1 Briefly, $10 \mathrm{~g}$ of activated carbon was equilibrated in $300 \mathrm{ml}$ model solution $(\sim 15 \mathrm{~g} / \mathrm{L}$ butanol $)$ at

$237{ }^{\circ} \mathrm{C}$ with agitation at $25 \mathrm{rpm}$ for $24 \mathrm{~h}$. After removing free water and un-adsorbed butanol with

3 filter paper and aspiration through a $50 \mathrm{ml}$ syringe, the partially dried adsorbents were heated

4 first at $40{ }^{\circ} \mathrm{C}$ to remove water, and then heated at $200{ }^{\circ} \mathrm{C}$ for butanol recovery.

$5 \quad 2.5$ Cultures and media

6 Clostridium beijerinckii CC101 (Lu et al., 2013) was used in serum bottle fermentation without

7 pH control. Clostridium acetobutylicum JB200 (Yang and Zhao, 2013) derived from ATCC

855025 was used for ABE fermentation in bioreactor with $\mathrm{pH}$ control. The seed culture was

9 prepared in Clostridial growth medium (CGM) containing $30 \mathrm{~g} / \mathrm{L}$ glucose, $2 \mathrm{~g} / \mathrm{L}$ yeast extract, 1

$10 \mathrm{~g} / \mathrm{L}$ Tryptone, minerals and vitamins in a phosphate buffer as described elsewhere (Xue et al.,

11 2012), and incubated at $37^{\circ} \mathrm{C}$ for $\sim 16 \mathrm{~h}$ until active growth was observed. The medium was

12 sterilized by autoclaving at $121{ }^{\circ} \mathrm{C}$ and $15 \mathrm{psig}$ for $30 \mathrm{~min}$. Batch fermentation was studied using

$13 \mathrm{P} 2$ medium containing glucose $(70 \mathrm{~g} / \mathrm{L})$, yeast extract $(1 \mathrm{~g} / \mathrm{L})$, phosphate buffer $\left(0.5 \mathrm{~g} / \mathrm{L} \mathrm{KH}_{2} \mathrm{PO}_{4}\right.$

14 and $\left.0.5 \mathrm{~g} / \mathrm{L} \mathrm{K}_{2} \mathrm{HPO}_{4}\right)$, ammonium acetate $(2.2 \mathrm{~g} / \mathrm{L})$, vitamins ( $1 \mathrm{mg} / \mathrm{L}$ para-amino-benzoic acid, 1

$15 \mathrm{mg} / \mathrm{L}$ thiamin and $0.01 \mathrm{mg} / \mathrm{L}$ biotin), and mineral salts $\left(0.2 \mathrm{~g} / \mathrm{L} \mathrm{MgSO} \cdot 7 \mathrm{H}_{2} \mathrm{O}, 0.01 \mathrm{~g} / \mathrm{L}\right.$

$16 \mathrm{MnSO}_{4} \cdot \mathrm{H}_{2} \mathrm{O}, 0.01 \mathrm{~g} / \mathrm{L} \mathrm{FeSO}{ }_{4} \cdot 7 \mathrm{H}_{2} \mathrm{O}, 0.01 \mathrm{~g} / \mathrm{L} \mathrm{NaCl}$ ). All solutions were purged with nitrogen for

$171 \mathrm{~h}$ through a sterile $0.2 \mu \mathrm{m}$ filter, either before or after autoclaving.

\section{$18 \quad 2.6$ Batch fermentation in serum bottles}

19 Batch fermentation was first studied with C. beijerinckii CC101 in serum bottles containing 80

$20 \mathrm{ml}$ of P2 medium and $4 \mathrm{~g}$ of an adsorbent (Norit ROW 0.8, Dowex SD-2, Dowex L-493, or

21 CBV901). Liquid samples were withdrawn with a syringe periodically for analysis of glucose,

22 free cell density and fermentation products. To evaluate the reusability of $\mathrm{AC}$ and the

23 reproducibility of fermentation performance with in situ adsorption, activated carbon in the 
1 serum bottles was collected and regenerated by heating at $200{ }^{\circ} \mathrm{C}$ to a constant weight, and then

2 washed with water for three times and used in the next batch fermentation. This was repeated for

35 cycles, with the initial and final glucose and butanol concentrations in the fermentation broth

4 recorded for each cycle.

\section{$5 \quad 2.7$ Fed-batch fermentation in bioreactor}

6 The integrated ABE fermentation with adsorption system consisted of a stirred-tank reactor (1.5

7 L working volume) and an external glass column (i.d.: $50 \mathrm{~mm}$, length: $400 \mathrm{~mm}, 250 \mathrm{ml}$ working

8 volume) packed with $75 \mathrm{~g}$ of activated carbon (Fig. 1A). The bioreactor with medium and the

9 activated carbon column were autoclaved separately for $45 \mathrm{~min}$, and aseptically connected after

10 sterilization. Before inoculation with $100 \mathrm{ml}$ of overnight culture of JB200 in serum bottles, the

11 whole system was sparged with nitrogen for $30 \mathrm{~min}$ to ensure an oxygen-free environment.

12 During fed-batch fermentation, a concentrated glucose solution ( $\sim 360 \mathrm{~g} / \mathrm{L})$ was pulse-fed when

13 glucose in the fermentation broth was nearly depleted. Adsorption was initiated by circulating the

14 fermentation broth between the fermentor and the adsorption column at $\sim 60 \mathrm{ml} / \mathrm{min}$ when the

15 butanol concentration in the fermentation broth had reached $\sim 10 \mathrm{~g} / \mathrm{L}$ (at $\sim 30 \mathrm{~h}$ ). Butanol

16 desorption and the regeneration of the adsorption column were done in an oven $\left(200{ }^{\circ} \mathrm{C}\right)$

17 connected a cold trap with a closed-loop vapor recirculation via a peristaltic pump (Fig. 1B). The

18 butanol collected in the cold trap was measured to determine the amount of butanol adsorbed in

19 the column. Similar fed-batch fermentation was also carried out with cells immobilized in a

20 fibrous matrix packed inside the stirred-tank bioreactor. The internal fibrous bed was made of a

21 piece of cotton towel wound together with a stainless steel mesh affixed to the inner wall of the

22 bioreactor. Batch fermentation without adsorption, as the control, was also carried out with an

23 initial glucose concentration of $\sim 85 \mathrm{~g} / \mathrm{L}$ at $37{ }^{\circ} \mathrm{C}$ and $\mathrm{pH}$ 5.0. 


\subsection{Analytical methods}

2 Cell biomass in the fermentation broth was estimated by measuring the optical density at $600 \mathrm{~nm}$

3 with a spectrophotometer (UV-16-1, Shimadzu, Columbia, MD). Glucose and fermentation

4 products were analyzed after cell removal through centrifugation at 13,200 rpm for $5 \mathrm{~min}$. The

5 glucose concentration was determined with YSI 2700 Select Biochemistry Analyzer (Yellow

6 Springs, Ohio). Butanol, acetone, ethanol, acetic acid and butyric acid were determined with a

7 gas chromatograph (GC-2014 Shimadzu, Columbia, MD) equipped with a flame ionization

8 detector (FID) and a fused silica column (Stabilwax-DA, $30 \mathrm{~m}$ long, $0.25 \mu \mathrm{m}$ film thickness and

$90.25 \mathrm{~mm}$ ID, Restek, Bellefonte, PA) following the method previously described (Xue et al.,

10 2012). All general lab supplies including pipette tips and centrifuge tubes were purchased from

11 Guangzhou Jet Bio-Filtration Co., Ltd., unless otherwise noted.

\section{3. Results and Discussion}

\section{$13 \quad 3.1$ Screening adsorbents for butanol adsorption}

14 Activated carbon, 2 zeolites and 6 ion-exchange resins from a candidate pool of commercially

15 available adsorbents were tested with a model solution containing $\sim 10 \mathrm{~g} / \mathrm{L} n$-butanol at $37{ }^{\circ} \mathrm{C}$.

16 The specific loadings and partition coefficients of these adsorbents are compared and shown in

17 Figure 1. Among them, activated carbon (Norit ROW 0.8) was the best adsorbent with the

18 highest specific loading $(q=0.21 \mathrm{~g}$ butanol $/ \mathrm{g}$ adsorbent $)$ and partition coefficient $\left(K_{r}=0.15 \mathrm{~g}\right.$

19 butanol/g adsorbent / $\mathrm{g}$ butanol/L). A high butanol adsorption capacity has also been reported for

20 activated carbon F-400 ( $q=0.302 \mathrm{~g} / \mathrm{g})$ (Abdehagh et al., 2015) and Norit ROW $0.8(q=0.252$

$21 \mathrm{~g} / \mathrm{g})($ Groot and Luyben, 1986). Among the six ion-exchange resins tested, Dowex Optipore

22 L-493 and SD-2 showed the best butanol adsorption capability $\left(q=0.14 \mathrm{~g} / \mathrm{g} ; K_{r}=0.034 \pm 0.01 \mathrm{~g}\right.$

23 butanol/g adsorbent / g butanol/L), which was somewhat lower than those previously reported $(q$ 
$1=0.175 \mathrm{~g} / \mathrm{g}$ for L-493 and $0.152 \mathrm{~g} / \mathrm{g}$ for SD-2), probably because a higher butanol concentration

2 of $20 \mathrm{~g} / \mathrm{L}$ was used in the precious study (Nielsen and Prather, 2009). For the zeolite group,

3 CBV901 $\left(q=0.15 \mathrm{~g} / \mathrm{g} ; K_{r}=0.037 \mathrm{~g}\right.$ butanol $/ \mathrm{g}$ adsorbent $/ \mathrm{g}$ butanol $\left./ \mathrm{L}\right)$ was significantly better

4 than CBV28014 $\left(q=0.11 \mathrm{~g} / \mathrm{g} ; K_{r}=0.032 \mathrm{~g}\right.$ butanol $/ \mathrm{g}$ adsorbent $/ \mathrm{g}$ butanol $\left./ \mathrm{L}\right)$, which was

5 consistent with the results from a previous study (Oudshoorn et al., 2009a). Norit ROW 0.8,

6 Dowex L-493, Dowex SD-2, and CBV901 each representing a different type of adsorbents with

7 a higher butanol adsorption capacity were thus further studied for their adsorption isotherms.

\section{$8 \quad 3.2$ Adsorption isotherm}

9 Figure 2 shows the adsorption isotherms at $37{ }^{\circ} \mathrm{C}$ and $60{ }^{\circ} \mathrm{C}$ for the four adsorbents studied. In

10 general, the specific loading for these adsorbents increased with increasing the butanol

11 concentration in solution and decreased with increasing the temperature from $37^{\circ} \mathrm{C}$ to $60{ }^{\circ} \mathrm{C}$. The

12 adsorption isotherm was fitted, via least-squares regression using Minitab, to the Langmuir

13 equation shown below:

$$
q=\frac{q_{m} C_{e q}}{K+C_{e q}}
$$

15 where $q(\mathrm{~g} / \mathrm{g})$ is the specific loading, $C_{e q}(\mathrm{~g} / \mathrm{L})$ is the equilibrium concentration of butanol in the 16 solution, $K(\mathrm{~g} / \mathrm{L})$ is the Langmiur coefficient, and $q_{m}(\mathrm{~g} / \mathrm{g})$ is the maximum adsorption capacity.

17 In general, the adsorption data fitted well with the Langmuir isotherm, which is commonly used

18 for modeling monolayer adsorption on homogeneous surfaces (Faisal et al., 2014; Lin et al.,

19 2012; Saravanan et al., 2010). Table 1 shows the model parameters for different adsorbents

20 tested. As expected, $q_{m}$ decreased with increasing the temperature from $37^{\circ} \mathrm{C}$ to $60{ }^{\circ} \mathrm{C}$ for all

21 adsorbents studied. The isotherm data confirmed that Norit ROW 0.8 was the best $n$-butanol

22 adsorbent with the highest $q_{m}$ value $(0.48 \mathrm{~g} / \mathrm{g})$ and the lowest $K$ value $(1.72 \mathrm{~g} / \mathrm{L})$ at $37{ }^{\circ} \mathrm{C}$,

23 followed by Dowex SD-2 $\left(q_{m}=0.38 \mathrm{~g} / \mathrm{g}, K=4.32 \mathrm{~g} / \mathrm{L}\right)$ and Dowex L-493 $\left(q_{m}=0.36 \mathrm{~g} / \mathrm{g}, K=\right.$ 
$14.02 \mathrm{~g} / \mathrm{L})$. CBV901 had the lowest adsorption capacity $\left(q_{m}=0.24 \mathrm{~g} / \mathrm{g}\right)$, but a good affinity $(K=$

$2 \quad 1.80 \mathrm{~g} / \mathrm{L})$ for $n$-butanol.

3 The adsorption isotherm of activated carbon was further studied with the model solution

4 simulating ABE fermentation broth, and the results are shown in Figure 2C. Compared to the

5 isotherm obtained with pure butanol solution (Fig. 2A), the amount of butanol adsorbed in the

6 presence of glucose, acetone, ethanol, and acetic and butyric acids was significantly lower

7 because of the competition for the active sites by mainly acetone and butyric acid (Abdehagh et

8 al., 2013). Nevertheless, Norit ROW 0.8 had a high selectivity (4.7-10.3) for butanol over

9 acetone and adsorbed much more butanol than acetone and acids (see supplemental Table S1).

$10 \quad 3.3$ Adsorption dynamics in a packed column of activated carbon

11 Figure 3 shows the breakthrough curves of continuous adsorption with butanol solution (Fig. 3A)

12 and a model solution containing ABE and acetic and butyric acids (Fig. 3B). With the $10 \mathrm{~g} / \mathrm{L}$

13 butanol solution, breakthrough started at $\sim 30 \mathrm{~min}$ and complete breakthrough occurred at $\sim 60$

$14 \min$ in the first cycle, while breakthrough started a little earlier in the second cycle. Based on the

15 breakthrough curve data, the amounts of butanol adsorbed were $8.88 \mathrm{~g}$ and $8.59 \mathrm{~g}$ in the first and

16 second cycles, respectively, with the corresponding specific loadings of $0.355 \mathrm{~g} / \mathrm{g}$ and $0.344 \mathrm{~g} / \mathrm{g}$,

17 which were comparable to the value $(\sim 0.36 \mathrm{~g} / \mathrm{g})$ found in the adsorption isotherm (Fig. 2A). The

18 data showed that AC could be regenerated and reused with a high efficiency (>97\%) without

19 losing much of its adsorption capacity. With the model solution containing ABE, butanol

20 breakthrough occurred much earlier due to the occupation of activate sites by other chemical

21 species. The order of breakthrough (acetic acid, acetone, ethanol, butyric acid, and butanol)

22 clearly indicated that butanol had higher adsorption by AC than other chemical species.

23 Overshoot observed with acetic acid, acetone, and ethanol suggested that their initial adsorption 
1 was later replaced by the stronger adsobate (butanol), which was also observed with other

2 adsorbents (Abdehagh et al., 2015; Lin et al., 2012). Based on the breakthrough curves, the

3 specific loadings were found to be: butanol $0.268 \mathrm{~g} / \mathrm{g}$, acetone $0.044 \mathrm{~g} / \mathrm{g}$, ethanol $0.011 \mathrm{~g} / \mathrm{g}$,

4 acetic acid $0.014 \mathrm{~g} / \mathrm{g}$, butyric acid $0.038 \mathrm{~g} / \mathrm{g}$. The results were consistent with the values found in

5 the adsorption isotherm (Fig. 2C) and confirmed that AC had higher adsorption capacity and

6 selectivity for butanol over acetone, ethanol, acetic acid, and butyric acid.

\section{$7 \quad 3.4$ Thermal desorption of butanol from activated carbon}

8 Figure 4 shows thermogravimetrical desorption of water, butanol and ABE mixture from Norit

9 ROW 0.8. It should be noted that more water was adsorbed on AC than butanol and ABE

10 mixtures. However, water adsorption was weaker than butanol adsorption, and water desorption

11 was faster with complete desorption at $\sim 125^{\circ} \mathrm{C}$, while complete butanol desorption occurred at a

12 much higher temperature of $\sim 200^{\circ} \mathrm{C}$. As can be seen in the thermogravimetrical desorption

13 curves, about $60 \%$ of the adsorbed water was desorbed when the heating temperature increased

14 to $100{ }^{\circ} \mathrm{C}$, which appeared to be an inflection point for decreased butanol desorption rate. The

15 results suggested that about $40 \%$ of the adsorbed butanol was more strongly adsorbed. For ABE,

16 about $80 \%$ of the adsorbed species were desorbed when the temperature had reached $\sim 113{ }^{\circ} \mathrm{C}$,

17 where an inflection point for decreased desorption rate was observed. The condensate collected

18 from desorption at $40{ }^{\circ} \mathrm{C}$ contained $\sim 60 \mathrm{~g} / \mathrm{L}$ butanol, while $\sim 150 \mathrm{~g} / \mathrm{L}$ butanol was obtained when

19 the heating temperature increased to $200{ }^{\circ} \mathrm{C}$. It is thus possible to obtain high-concentration

20 butanol at higher temperatures after removing most of the adsorbed water at lower temperatures.

21 Similar finding was reported for ACF-400 that thermal desorption generated a high butanol

22 concentration of $\sim 150 \mathrm{~g} / \mathrm{L}$ in the desorbed phase with a consistent recovery rate of $\sim 80 \%$ in 7

23 adsorption-desorption cycles using ABE model solutions (Abdehagh et al., 2015). A much higher 
1 butanol concentration of $\sim 80 \%$ (w/v) could be obtained from a two-step desorption process using

2 silicalite and zeolites, which have a much higher selectivity for butanol over water (Milestone

3 and Bibby, 1981; Saravanan et al., 2010). However, they are not compatible with ISPR due to

4 their toxicity to cells.

$5 \quad$ Heat or energy required for thermal desorption includes evaporation heat or enthalpy for

6 vaporizing butanol and water and sensible heat to heat up the temperature from $37{ }^{\circ} \mathrm{C}$ to $125^{\circ} \mathrm{C}$

7 for water and $200{ }^{\circ} \mathrm{C}$ for butanol and $\mathrm{AC}$, and is estimated to be $\sim 14.1 \mathrm{~kJ} / \mathrm{g}$ butanol desorbed (see

8 Table 2), which is much smaller than the energy content of butanol (36 kJ/g). It is noted that the

9 total energy consumption for butanol recovery and purification is mostly for product capture or

10 concentrating the dilute butanol solution ( 1\%) to more than 50\% (w/v) (Oudshoorn et al.,

11 2009b). It is clear that adsorption with AC can provide an energy-efficient process for biobutanol

12 production and is more favorable than conventional distillation, which requires more than 24-50

$13 \mathrm{~kJ} / \mathrm{g}$ butanol) (Matsumura et al., 1988). Since the majority ( 89\%) of the heat for butanol

14 desorption from AC was to vaporize water, which has a much higher heat capacity and

15 evaporation enthalpy than butanol, it would be desirable to reduce the amount of water adsorbed

16 in the process in order to further reduce energy consumption in desorption.

\section{$17 \quad 3.4$ Batch fermentation with in situ adsorption in serum bottles}

18 The effects of in situ butanol adsorption with Norit ROW 0.8, Dowex L-493, Dowex SD-2, and

19 CBV901, respectively, on batch fermentation with C. beijerinckii CC101 were studied in serum

20 bottles. The results are summarized and compared to the control without adsorption in Table 3.

21 The initial glucose concentration in the medium was $\sim 70 \mathrm{~g} / \mathrm{L}$, and the broth $\mathrm{pH}$ dropped from the

22 initial value of $\sim 6.5$ to $4.2-4.6$, depending on the adsorbent used, due to acids accumulation in

23 the acidogenesis phase. With Norit ROW 0.8, almost all glucose was utilized in the fermentation, 
1 producing a total of $21.9 \mathrm{~g} / \mathrm{L}$ butanol at a yield of $0.31 \mathrm{~g} / \mathrm{g}$ glucose consumed. The fermentations

2 with Dowex L-493 and SD-2 produced $14.5 \mathrm{~g} / \mathrm{L}$ and $15.2 \mathrm{~g} / \mathrm{L}$ butanol, respectively, at a yield of

$3 \quad 0.31 \mathrm{~g} / \mathrm{g}$, with $24.5 \mathrm{~g} / \mathrm{L}$ and $20.4 \mathrm{~g} / \mathrm{L}$ glucose, respectively, remaining in the broth when the

4 fermentation ceased. In contrast, the control fermentation produced only $11.7 \mathrm{~g} / \mathrm{L}$ butanol at a

5 yield of $0.27 \mathrm{~g} / \mathrm{g}$, with $28.5 \mathrm{~g} / \mathrm{L}$ glucose remaining unused in the broth. The fermentation ceased

6 due to strong inhibition by butanol at $>10 \mathrm{~g} / \mathrm{L}$ (Xu et al., 2015). Clearly, in situ butanol

7 adsorption improved the fermentation by alleviating butanol toxicity. However, butanol

8 production was not improved with CBV901, which gave similar butanol production (11.5 g/L)

9 and glucose utilization to those of the control, even though a significant amount of produced

10 butanol was also adsorbed, suggesting that the hydrophobic CBV901 was toxic to cells and not

11 compatible with the fermentation for in situ butanol adsorption.

12 The reproducibility of the fermentation performance with the regenerated Norit ROW 0.8

13 was also evaluated in serum bottles, and the results showed that consistent fermentation results

14 were obtained in all five cycles (see Table 4), indicating that the heat-regenerated AC could be

15 reused with stable adsorption performance.

$16 \quad 3.5$ Fermentation with butanol adsorption in bioreactor

17 ABE fermentation was studied with free cells of C. acetobutylicum JB200 in a stirred-tank

18 bioreactor with $\mathrm{pH}$ controlled at $\sim 5.0$. With the medium initially containing $\sim 85 \mathrm{~g} / \mathrm{L}$ of glucose,

$1918.3 \mathrm{~g} / \mathrm{L}$ butanol was produced in $\sim 54 \mathrm{~h}($ Fig. 5A $)$, giving a butanol productivity of $\sim 0.34 \mathrm{~g} / \mathrm{L} \cdot \mathrm{h}$

20 and yield of $0.22 \mathrm{~g} / \mathrm{g}$ glucose consumed. Fed-batch fermentation was then studied with

21 adsorption through an external column of activated carbon. Butanol adsorption was initiated by

22 circulating the broth between the fermentor and adsorption column when butanol concentration

23 in the broth had reached $\sim 10 \mathrm{~g} / \mathrm{L}$. Concentrated glucose solution was pulse-fed to the bioreactor 
1 several times until the fermentation stopped at $\sim 106 \mathrm{~h}$ when the butanol concentration in the

2 fermentation broth reached $18.7 \mathrm{~g} / \mathrm{L}$ (Fig. 5B). Thermal desorption by heating the activated

3 carbon column at $200{ }^{\circ} \mathrm{C}$ resulted in a solution containing $167.1 \mathrm{~g} / \mathrm{L}$ butanol, $20.5 \mathrm{~g} / \mathrm{L}$ acetone,

$4 \quad 2.8 \mathrm{~g} / \mathrm{L}$ ethanol, $3.7 \mathrm{~g} / \mathrm{L}$ acetic acid and $0.9 \mathrm{~g} / \mathrm{L}$ butyric acid with a total volume of $112.5 \mathrm{ml}$. The

5 total amount of butanol obtained from desorption was $18.8 \mathrm{~g}$ butanol, which was only $\sim 80 \%$ of

6 the butanol ( $23.5 \mathrm{~g})$ adsorbed in the column based on the estimation from the adsorption

7 isotherm. The less than $100 \%$ recovery of butanol from thermal desorption was due to loss in

8 collecting the condensate in the system. Thus, $\sim 16.1 \mathrm{~g} / \mathrm{L}$ butanol produced in the fermentation

9 was adsorbed. With adsorption, the total butanol production increased $\sim 90 \%$ due to alleviated

10 butanol inhibition, but butanol yield and productivity were similar to those of the control without

11 adsorption (see Table 5). The fermentation stopped due to the high level of butanol in the

12 fermentation broth accumulated and not effectively removed by adsorption, due to the saturation

13 of activated carbon with butanol by $\sim 80 \mathrm{~h}$ as indicated by the rapid increase in butanol and

14 acetone in the broth.

15 The fermentation was then studied with cells immobilized in the cotton cloth packed inside

16 the bioreactor, initially operated in a repeated batch mode without adsorption (Fig. 6A), followed

17 with adsorption operated in a fed-batch mode (Fig. 6B). In the repeated batch fermentation, the

18 fermentation broth was drained and replaced with fresh medium at the end of each batch to start

19 a new batch with cells already immobilized in the bioreactor. Consistent fermentation

20 performance with $16-18 \mathrm{~g} / \mathrm{L}$ butanol produced from $\sim 77 \mathrm{~g} / \mathrm{L}$ glucose consumed in $\sim 48 \mathrm{~h}$, with a

21 butanol yield of $\sim 0.21 \mathrm{~g} / \mathrm{g}$ glucose and productivity of $\sim 0.34 \mathrm{~g} / \mathrm{L} \cdot \mathrm{h}$, was obtained in all three

22 batches, which were similar to those from the free-cell fermentation (see Table 5). In the

23 subsequent fed-batch fermentation with activated carbon adsorption, the broth was circulated 
1 between the fermentor and the adsorption column when the butanol concentration had reached

$2 \sim 10 \mathrm{~g} / \mathrm{L}$. The adsorption column was replaced with a new one containing fresh (regenerated)

3 activated carbon when butanol concentration in the broth exceeded $\sim 10 \mathrm{~g} / \mathrm{L}$. A total of three

4 columns of activated carbon (connected at $170,195.5$ and $216.5 \mathrm{~h}$, respectively) were used for

5 butanol adsorption in the fed-batch fermentation, which kept the butanol concentration in the

6 fermentation broth below $\sim 10 \mathrm{~g} / \mathrm{L}$ and allowed the fermentation to continue without butanol

7 poisoning. However, the fermentation gradually slowed down to eventually halt at a high

8 acetone concentration of $\sim 18 \mathrm{~g} / \mathrm{L}$. The selective adsorption of butanol by activated carbon

9 resulted in the accumulation of acetone, which became toxic and limited the ABE fermentation.

10 Similar finding has also been reported (Liu et al., 2014).

11 Based on the adsorption isotherm (Fig. 3) and butanol concentration in the fermentation

12 broth, the total amount of butanol adsorbed on the activated carbon was estimated to be $\sim 73.0 \mathrm{~g}$,

13 suggesting that $\sim 45.7 \mathrm{~g} / \mathrm{L}$ butanol produced in the fed-batch fermentation were adsorbed. Thus, a

14 total of $\sim 54.6 \mathrm{~g} / \mathrm{L}$ butanol was produced from $260 \mathrm{~g} / \mathrm{L}$ glucose in $122 \mathrm{~h}$ in the fermentation, with

15 an overall butanol yield of $\sim 0.22 \mathrm{~g} / \mathrm{g}$ and productivity of $\sim 0.45 \mathrm{~g} / \mathrm{L} \cdot \mathrm{h}$. Compared to the control

16 without adsorption, butanol adsorption with activated carbon increased total butanol production

17 by $\sim 230 \%$ and productivity by $\sim 32 \%$ in the immobilized-cell fermentation (see Table 5). It is

18 thus clear that activated carbon adsorption for in situ removal of butanol from the fermentation

19 broth can greatly improve ABE fermentation. However, the process may be limited by acetone

20 accumulation as activated carbon had a relatively low acetone adsorption capacity. One solution

21 to this acetone inhibition problem is to use a Clostridium strain such as the engineered $C$.

22 tyrobutyricum that does not produce acetone (Du et al., 2015; Yu et al., 2011).

\section{$23 \quad 3.6$ Comparison to other studies}


1 Adsorption for in situ butanol recovery from butanol fermentation has been studied as an

2 effective method to alleviate butanol toxicity and thus increase substrate utilization and butanol

3 production in ABE fermentation (Groot et al., 1992; Qureshi et al., 2005; Staggs and Nielsen,

4 2015). Groot and Luyben (1986) first studied the effect of several adsorbents on fermentation by

5 C. beijerinckii LMD 27.6 and found that only the polymeric resin XAD-8 increased butanol

6 production to $\sim 8.5 \mathrm{~g} / \mathrm{L}$ (vs. $5.5 \mathrm{~g} / \mathrm{L}$ for the control), while activated carbon Norit W52 and other

7 polymeric resins had more acids but less butanol production (see Table 6), probably because

8 adsorption of acids allowed cells to continue acidogenesis without shifting to solventogenesis.

9 Yang et al. (1994) used polyvinylpyridine (PVP) ion exchange resin (Reillex 425) to adsorb

10 butanol in batch fermentation with C. acetobutylicum and reported that total ABE production

11 increased $54 \%$ (from $21 \mathrm{~g} / \mathrm{L}$ to $29.8 \mathrm{~g} / \mathrm{L}$ ) and productivity increased $130 \%$ to $0.92 \mathrm{~g} / \mathrm{L} \cdot \mathrm{h}$ when the

12 fermentation broth contained $\sim 30 \%$ (w/w) of the adsorbent, compared to the control without the

13 adsorbent. In this study, the total butanol production increased to $14.1 \mathrm{~g} / \mathrm{L}-17.5 \mathrm{~g} / \mathrm{L}$ (vs. $11 \mathrm{~g} / \mathrm{L}$ )

14 with 5\%-30\% of the resin for in situ butanol adsorption. Later with the PVP resin in a packed

15 column for butanol adsorption, a total of $27.7 \mathrm{~g} / \mathrm{L}$ butanol at a productivity of $0.99 \mathrm{~g} / \mathrm{L} \cdot \mathrm{h}$ was

16 attained in repeated fed-batch fermentation with cell recycle (Yang and Tsao, 1995). Although

17 these studies demonstrated the feasibility and benefits of adsorption in the ISPR for ABE

18 fermentation, the adsorbents used had a low adsorption capacity $(q<0.1 \mathrm{~g} / \mathrm{g})$. More recently,

19 Nielsen and Prather (2009) screened a variety of commercial resins and found that Dowex

20 Optipore SD-2 had a high butanol adsorption capacity ( $q=0.266-0.403 \mathrm{~g} / \mathrm{g}$ resin) and the

21 addition of 5\% (w/v) SD-2 in the ABE fermentation by C. acetobutylicum ATCC 824 increased

22 butanol production to $22.2 \mathrm{~g} / \mathrm{L}$, a $86 \%$ increase compared to the control without SD-2. However,

23 adding more SD-2 in the fermentation was not beneficial and showed negative effect due to the 
1 adsorption of glucose and other nutrients present in the medium. Similarly, butanol production

2 by ATCC 824 increased $\sim 124 \%$ to $27.1 \mathrm{~g} / \mathrm{L}$ with butanol adsorption using an expanded bed of

3 Dowex Optipore L-493 (Wiehn et al., 2014). Liu et al. (2014) used a macroporous cross-linked

4 polystyrene resin KA-I for butanol adsorption in a fixed bed column connected to a biofilm

5 reactor, and fed-batch fermentation with C. acetobutylicum B3 produced 38.2-58.3 g/L butanol

6 with a butanol yield of $0.19-0.20 \mathrm{~g} / \mathrm{g}$ glucose. The higher production was achieved when both

7 butanol and acetone were adsorbed, while the lower butanol production was limited by acetone

8 inhibition. Butanol production was further increased to $92.6 \mathrm{~g} / \mathrm{L}$ when methyl viologen (MV)

9 was added to modulate the redox. MV as an artificial electron carrier can inhibit hydrogen

10 production and thus increase NADH availability for butanol production (Du et al., 2015).

11 In the present study, we used activated carbon Norit ROW 0.8 in a packed column for

12 butanol adsorption in fed-batch fermentation, which gave a total butanol production of $54.6 \mathrm{~g} / \mathrm{L}$,

13 comparable to those obtained with KA-I and higher than those with PVP, Dowex SD-2, and

14 L-493 (see Table 6). It should be noted that Norit ROW 0.8 has a much higher butanol adsorption

15 capacity than that of KA-I and PVP (see Table 6). Unlike KA-I and PVP, Norit ROW 0.8 also has

16 a low affinity with acetic and butyric acids. Adsorption of these acids not only would reduce

17 butanol adsorption capacity, but also could decrease butanol production (Groot and Luyben,

18 1986) and result in a butanol product containing undesirable acids after desorption. Furthermore,

19 activated carbon is also the most economical adsorbent with a much lower price (less than $\$ 5 / \mathrm{kg}$ )

20 compared to polymeric resins $(>\$ 100 / \mathrm{kg})$ and zeolites $(\sim 250 / \mathrm{kg})$. In addition, AC could

21 detoxify plant biomass hydrolysates containing inhibitors, including furfural, organic acids, and

22 phenolics, derived from degradation of sugars (glucose and xylose) and lignin in the pretreatment

23 process (Zhang et al., 2016) and greatly increase butanol production in ABE fermentation (Liu et 
1 al., 2015; Lu et al., 2013). These inhibitors are usually present at low concentrations ( $<1 \mathrm{~g} / \mathrm{L})$

2 and should not interfere with butanol adsorption, which would require experimental verification

3 in future studies.

4 Butanol can be desorbed from the adsorbent by heating, stripping, or displacement

5 (Oudshoorn et al., 2012). Butanol adsorbed on PVP and KA-I resins was recovered by washing

6 with methanol, resulting in a six-fold concentrated butanol solution (Lin et al., 2012). However,

7 resins must be further regenerated by washing with water. Vacuum was used to recover $81 \%$

8 butanol from Dowex L-493, resulting in a condensate containing $85.8 \mathrm{~g} / \mathrm{L}$ butanol (Wiehn et al.,

9 2013). Butanol recovery from Dowex SD-2 via thermal treatment at $100{ }^{\circ} \mathrm{C}$ had a recovery rate

10 of $\sim 84 \%$ and the desorbed phase after condensation contained $>107 \mathrm{~g} / \mathrm{L}$ butanol (Nielsen and

11 Prather, 2009). In the present study, butanol desorption from $\mathrm{AC}$ at $200{ }^{\circ} \mathrm{C}$ gave a high butanol

12 concentration of $\sim 167 \mathrm{~g} / \mathrm{L}$ in the condensate, which was far exceeding $n$-butanol solubility, $\sim 7.7 \%$

13 (w/w) in water at $20{ }^{\circ} \mathrm{C}$, and spontaneously formed two phases with the upper organic phase

14 having a high butanol concentration of $\sim 640 \mathrm{~g} / \mathrm{L}$. Clearly, thermal desorption is effective for the

15 regeneration of and butanol recovery from activated carbon.

16 In general, butanol adsorption with AC is competitive with other novel separation methods,

17 including gas stripping, pervaporation and solvent extraction (Groot et al., 1992; Oudshoorn et

18 al., 2009b; Qureshi et al., 2005; Xue eta al., 2014a). Energy requirements (kJ/g butanol) for

19 butanol recovery from dilute solution $(\sim 1.0 \%$ butanol) by various separation methods are

20 compared in supplemental Table S2. The advantages and disadvantages of adsorption vs. other

21 methods have been discussed in details in a recent review paper (Xue et al., 2014a). One

22 advantage for adsorption is its relatively fast adsorption and desorption processes. The adsorbent

23 could quickly remove $\mathrm{ABE}$ from the fermentation broth in a single pass. In contrast, gas 
1 stripping, pervaporation, and extraction are slower processes, requiring a large volume of gas or

2 extractant for stripping (extraction) in multiple passes and a large contacting surface area

3 between the two phases for mass transfer. Gas stripping and pervaporation also require a

4 sub-zero temperature for condensing ABE vapors. On the other hand, adsorption requires a

5 desorption step for adsorbent regeneration, and direct contact of fermentation broth with the

6 adsorbent could cause fouling and other operation difficulties. Both adsorption and gas stripping

7 have a moderate selectivity (against water) of $\sim 15$ and energy requirement of $\sim 20 \mathrm{~kJ} / \mathrm{g}$ butanol.

8 The selectivity of adsorption can be improved by screening and selecting from a large pool of

9 adsorbents, while the selectivity of gas stripping is limited by gas-liquid equilibrium. The high

10 cost of adsorbents and additional equipment (capital) cost have hindered the commercial

11 application of adsorption in ABE fermentation, which, however, could be largely alleviated by

12 choosing relatively inexpensive activated carbon such as the one used in this study. In summary,

13 ABE fermentation with in situ butanol adsorption by activated carbon offers an energy-efficient

14 and economically competitive process for biobutanol production.

\section{4. Conclusions}

16 Various adsorbents were screened and activated carbon was found to have the best specific

17 loading and partitioning coefficient for butanol. Fed-batch fermentation with in situ adsorption

18 by activated carbon produced $54.6 \mathrm{~g} / \mathrm{L}$ butanol at a productivity of $0.45 \mathrm{~g} / \mathrm{L} \cdot \mathrm{h}$, increasing by $230 \%$

19 and 32\%, respectively, compared to the control without adsorption. Thermal desorption produced

20 a condensate containing $\sim 167 \mathrm{~g} / \mathrm{L}$ butanol, which was concentrated to $\sim 640 \mathrm{~g} / \mathrm{L}(80 \%$, v/v) after

21 phase separation. This ISPR process with a low energy consumption of $\sim 14.1 \mathrm{~kJ} / \mathrm{g}$ butanol

22 exhibits great potential for economical biobutanol production. 


\section{Acknowledgments}

2 This work was supported in part by the Ohio Department of Development-Third Frontier

3 Advanced Energy Program (Tech 08-036), the National Science Foundation STTR program

4 (IIP-1026648), Advanced Research Projects Agency-Energy (DE-AR0000095), and the National

5 Natural Science Foundation of China (NSFC 21306020 and 21576045). We thank Dr. Zhenchao

6 Sun at Ohio State University for assistance in the thermogravimetrical desorption measurement. 


\section{References}

1. Abdehagh, N., Tezel, F.H., Thibault, J., 2013. Adsorbent screening for biobutanol separation by adsorption: kinetics, isotherms and competitive effect of other compounds. Adsorption 19: $1263-1272$.

2. Abdehagh, N., Tezel, F.H., Thibault, J., 2014. Separation techniques in butanol production: Challenges and developments. Biomass Bioenergy 60: 222-246.

3. Abdehagh, N., Gurnani, P., Tezel, F.H., Thibault, J., 2015. Adsorptive separation and recovery of biobutanol from ABE model solutions. Adsorption 21, 185-194.

4. Agueda, V.I., Delgado, J.A., Uguina, M.A., Sotelo, J.L., Garcia, A., 2013. Column dynamics of an adsorption-drying-desorption process for butanol recovery from aqueous solutions with silicalite pellets. Sep. Purifi. Technol. 104, 307-321.

5. Du, Y., Jiang, W., Yu, M., Tang, I.-C., Yang, S.T., 2015. Metabolic process engineering of Clostridium tyrobutyricum $\Delta$ ack-adhE2 for enhanced $n$-butanol production from glucose: effects of methyl viologen on NADH availability, flux distribution, and fermentation kinetics. Biotechnol. Bioeng. 112, 705-715.

6. Dürre, P., 1998. New insights and novel developments in clostridial acetone/butanol/isopropanol fermentation. Appl. Microbiol. Biothnol. 49, 639-648.

7. Faisal, A., Zarebska, A., Saremi, P., Korelskiy, D., Ohlin, L., Rova, U., Hedlund, J., Grahn, M., 2014. MFI zeolite as adsorbent for selective recovery of hydrocarbons from ABE fermentation broths. Adsorption 20, 465-470.

8. Groot, W.J., Luyben, K.C.A.M., 1986. In situ product recovery by adsorption in the butanol isopropanol batch fermentation. Appl. Microbiol. Biothnol. 25, 29-31.

9. Groot, W.J., Vanderlans, R.G.J.M., Luyben, K.C.A.M., 1992. Technologies for butanol recovery integrated with fermentations. Process Biochem. 27, 61-75.

10. Kumar, M., Gayen, K., 2011. Developments in biobutanol production: new insights. Appl. Energy 88, 1999-2012.

11. Lee, S.Y., Park, J.H., Jang, S.H., Nielsen, L.K., Kim, J., Jung, K.S., 2008. Fermentative butanol production by clostridia. Biotechnol. Bioeng. 101, 209-228.

12. Lin, X., Wu, J., Jin, X., Fan, J., Li, R., Wen, Q., Qian, W., Liu, D., Chen, X., Chen, Y., Xie, J., Bai, J., Ying, H., 2012. Selective separation of biobutanol from acetone-butanol-ethanol fermentation broth by means of sorption methodology based on a novel macroporous resin. Biotechnol. Prog., 28, 962-972.

13. Liu, D., Chen, Y., Ding, F.Y., Zhao, T., Wu, J.L., Guo, T., Ren, H.F., Li, B.B., Niu, H.Q., Cao, Z., Lin, 
X.Q., Xie, J.J., He, X.J., Ying, H.J., 2014. Biobutanol production in a Clostridium acetobutylicum biofilm reactor integrated with simutaneous product recovery by adsorption. Biotechnol. Biofuels 7 , 5.

14. Liu, K., Atiyeh, H.K., Pardo-Planas, O., Ezeji, T.C., Ujor, V., Overton, J.C., Berning, K., Wilkins, Mark, R., Tanner, R.S., 2015. Butanol production from hydrothermolysis-pretreated switchgrass: Quantification of inhibitors and detoxification of hydrolysate. Bioresour. Technol. 189, 292-301.

15. Lu, C., Dong, J., Yang, S.T., 2013. Butanol production from wood pulping hydrolysate in an integrated fermentation-gas stripping process. Bioresour. Technol. 143, 467-475.

16. Milestone, N.B., Bibby, D.M., 1981. Concentration of alcohols by adsorption on silicalite. J. Chem. Technol. Biotechnol. 31, 732-736.

17. Matsumura, M., Kataoka, H., Ibaraki, Sueki, M., Araki, K., Yokohama, 1988. Energy saving effect of pervaporation using oleyl alcohol liquid membrane in butanol purification. Bioprocess Eng. 3, 93-100.

18. Nielsen, D.R., Prather, K.J., 2009. In situ product recovery of n-butanol using polymeric resins. Biotechnol. Bioeng. 102, 811-821.

19. Nielsen, D.R., Amarasiriwardena, G.S., Prather K.L.J., 2010. Predicting the adsorption of second generation biofuels by polymeric resins with applications for in situ product recovery (ISPR). Bioresour. Technol. 101, 2762-2769.

20. Oudshoorn, A., van der Wielen, L.A.M., Straathof, A.J.J., 2009a. Adsorption equilibria of bio-based butanol solutions using zeolite. Biochem. Eng. J. 48, 99-103.

21. Oudshoorn, A., van der Wielen, L.A.M., Straathof, A.J.J., 2009b. Assessment of options for selective 1-butanol recovery from aqueous solution. Ind. Eng. Chem. Res. 48, 7325-7336.

22. Oudshoorn, A., van der Wielen, L.A.M., Straathof, A.J.J., 2012. Desorption of butanol from zeolite material. Biochem. Eng. J. 67, 167-172.

23. Qureshi, N., Hughes, S., Maddox, I.S., Cotta, M.A., 2005. Energy-efficient recovery of butanol from model solutions and fermentation broth by adsorption. Bioprocess Biosyst. Eng. 27, 215-222.

24. Roffler, S.R., Blanch, H.W., Wilke, C.R., 1987. In-situ recovery of butanol during fermentation. Part 1: Batch extractive fermentation, Bioproc. Eng. 2, 1-12.

25. Saravanan, V., Waijers, D.A., Ziari, M., Noordermeer, M.A., 2010. Recovery of 1-butanol from aqueous solutions using zeolite ZSM-5 with a high $\mathrm{Si} / \mathrm{Al}$ ratio; suitability of a column process for industrial applications. Biochem. Eng. J. 49, 33-39.

26. Staggs, K.W., Nielsen, D.R., 2015. Improving n-butanol production in batch and semi-continuous processes through integrated product recovery. Process Biochem. 50, 1487-1498.

27. Vane, L.M., 2008. Separation technologies for the recovery and dehydration of alcohols from 
fermentation broths. Biofuel Bioprod. Biorefin. 2, 553-588.

28. Wang, J., Yang, X., Chen, C.C., Yang, S.T., 2014. Engineering clostridia for butanol production from biorenewable resources: from cells to process integration. Curr. Opin. Chem. Eng. 6, 43-54.

29. Wiehn, M., Staggs, K., Wang, Y.C., Nielsen, D.R., 2014. In situ butanol recovery from Clostridium acetobutylicum fermentations by expanded bed adsorption. Biotechnol. Prog. 30, 68-78.

30. Xu, M., Zhao, J., Yu, L., Tang, I.C., Xue, C., Yang, S. T., 2015. Engineering Clostridium acetobutylicum with a histidine kinase knockout for enhanced $n$-butanol tolerance and production. Appl. Microbiol. Biotechnol. 99, 1011-1022.

31. Xue, C., Zhao, J., Lu, C., Yang, S.T., Bai, F., Tang, I.C., 2012. High-titer n-butanol production by Clostridium acetobutylicum JB200 in fed-batch fermentation with intermittent gas stripping. Biotechnol. Bioeng. 109, 2746-2756.

32. Xue, C., Zhao, X.Q., Liu, C.G., Chen, L.J., Bai, F.W., 2013a. Prospective and development of butanol as an advanced biofuel. Biotechnol. Adv., 31, 1575-1584.

33. Xue, C., Zhao, J.B., Liu, F.F., Lu, C.C., Yang, S.T., Bai, F.W., 2013b. Two-stage in situ gas stripping for enhanced butanol fermentation and energy-saving product recovery. Bioresour. Technol. 135, 396-402.

34. Xue, C., Zhao, J.B., Chen, L.J., Bai, F.W., Yang, S.T., Sun, J.X., 2014a. Integrated butanol recovery for an advanced biofuel: current state and prospects. Appl. Microbiol. Biotechnol., 98, 3463-3474.

35. Xue, C., Du, G.Q., Chen, L.J., Ren, J.G., Bai, F.W., 2014b. Evaluation of asymmetric polydimethylsiloxane-polyvinylidene fluoride composite membrane and incorporated with acetone-butanol-ethanol fermentation for butanol recovery. J. Biotechnol., 188, 158-165.

36. Xue, C., Du, G.Q., Sun, J.X., Chen, L.J., Gao, S.S., Yu, M.L., Yang, S.T., Bai, F.W., 2014c. Characterization of gas stripping and its integration with acetone-butanol-ethanol fermentation for high-efficient butanol production and recovery. Biochem. Eng. J., 83, 55-61.

37. Yang, S.T., Lu, C., 2013. Extraction-fermentation hybrid (extractive fermentation), in Ramaswamy S, Ramarao BV, Huang H (eds.), Separation and Purification Technologies in Biorefineries, John Wiley \& Sons, Ltd, Chichester, UK. Chapter 15. pp 409-437.

38. Yang, X., Tsai, G.J., Tsao, G.T., 1994. Enhancement of in-situ adsorption on the acetone-butanol fermentation by Clostridium acetobutylicum. Sep. Technol. 4, 81-92.

39. Yang, X., Tsao, G.T., 1995. Enhanced acetone-butanol fermentation using repeated fed-batch operation coupled with cell recycle by membrane and simultaneous removal of inhibitory products by adsorption, Biotechnol. Bioeng. , 47, 444-450.

40. Yang, S.T., Zhao, J.B., 2013. Adaptive engineering of Clostridium for increased butanol production. US Patent 8450093. 
41. Yu, M., Zhang, Y., Tang, I.C., Yang, S.T., 2011. Metabolic engineering of Clostridium tyrobutyricum for $n$-butanol production. Metab. Eng. 13, 373-382.

42. Zhang, L., Li, X., Yong, Q., Yang, S.T., Ouyang, J., Yu S., 2016. Impacts of lignocellulose-derived inhibitors on L-lactic acid fermentation by Rhizopus oryzae, Bioresourc. Technol., 203: 173-180.

43. Zhao, J.B., Lu, C.C., Chen, C.C., Yang, S.T., 2013. Biological production of butanol and higher alcohols, in: Yang, S.T., EI-Enshasy, H.A., Thongchul, N. (Eds.), Bioprocessing technologies in biorefinery for sustainable production of fuels, chemicals and polymers. Wiley, New York, pp. 235-261. 


\section{Figure Captions}

Figure 1. Specific loadings and partition coefficients of various adsorbents for butanol in a screening test using a model solution containing $10 \mathrm{~g} / \mathrm{L}$ butanol.

Figure 2. Equilibrium isotherms of $n$-butanol with Norit ROW0.8, CBV901, Dowex L-493 and Dowex SD-2 at $37{ }^{\circ} \mathrm{C}(\mathrm{A})$ and $60{ }^{\circ} \mathrm{C}(\mathrm{B})$. Data are fitted with the Langmuir model. C. Equilibrium isotherms of n-butanol and acetone with Norit ROW0.8 in a simulated ABE fermentation broth at $37^{\circ} \mathrm{C}$.

Figure 3. Dynamics of continuous adsorption in a packed column of activated carbon with butanol solution (A) and a model solution containing ABE and acetic and butyric acids (B).

Figure 4. Thermogravimetrical desorption of $n$-butanol, water, and ABE mixture (3:6:1), respectively, from activated carbon. Curves show percentage weight changes in mass adsorbed (relative to the initial weight) as temperature increased from 25 to $250{ }^{\circ} \mathrm{C}$.

Figure 5. Kinetics of ABE fermentation of C. acetobutylicum JB200 at $37{ }^{\circ} \mathrm{C}$. A. Batch free-cell fermentation without adsorption (control); B. Fed-batch free-cell fermentation with adsorption. An activated carbon column was connected to the fermentation at $30 \mathrm{~h}$ when the butanol concentration in the fermentation broth was $\sim 10 \mathrm{~g} / \mathrm{L}$

Figure 6. Kinetics of ABE fermentation of C. acetobutylicum JB200 at $37{ }^{\circ}$ C. A. Repeated-batch immobilized-cell fermentation without adsorption (control); D. Fed-batch immobilized-cell fermentation with adsorption. Fresh or regenerated activated carbon column was connected to the fermentation at $170,195.5$ and $216.5 \mathrm{~h}$, respectively. 
Table 1. Langmuir isotherm parameters for butanol adsorption from least-squares regression

\begin{tabular}{lcccc}
\hline \multirow{2}{*}{ Adsorbents } & \multicolumn{2}{c}{$37^{\circ} \mathrm{C}$} & \multicolumn{2}{c}{$60{ }^{\circ} \mathrm{C}$} \\
\cline { 2 - 5 } & $K(\mathrm{~g} / \mathrm{L})$ & $q_{m}(\mathrm{~g} / \mathrm{g})$ & $K(\mathrm{~g} / \mathrm{L})$ & $q_{m}(\mathrm{~g} / \mathrm{g})$ \\
\hline Norit ROW 0.8 & 1.72 & 0.48 & 2.01 & 0.45 \\
CBV901 & 1.80 & 0.24 & 1.11 & 0.21 \\
Dowex L-493 & 4.02 & 0.36 & 4.02 & 0.33 \\
Dowex SD-2 & 4.32 & 0.38 & 4.93 & 0.31 \\
\hline
\end{tabular}


Table 2. Estimation of heat required for desorption of butanol from activated carbon

\begin{tabular}{|c|c|c|c|c|c|}
\hline $\begin{array}{l}\text { Species } \\
\text { (amount) }\end{array}$ & $C_{p}(\mathrm{~J} / \mathrm{g} \cdot \mathrm{K})$ & $\Delta \mathrm{H}_{\text {evap }}(\mathrm{J} / \mathrm{g})$ & $\begin{array}{c}\text { Sensible heat } \\
(\mathrm{J} / \mathrm{g})^{1}\end{array}$ & $\begin{array}{c}\text { Total energy } \\
(\mathrm{J} / \mathrm{g})\end{array}$ & $\begin{array}{l}\text { Total heat for } \\
\text { desorption } \\
(\mathrm{J} / \mathrm{g} \text { butanol })^{2}\end{array}$ \\
\hline Butanol (1 g) & 2.39 & 585 & 389.57 & 974.57 & 975 \\
\hline Water (4.8 g) & 4.18 & 2258 & 367.84 & 2625.84 & 12,604 \\
\hline $\mathrm{AC}(4 \mathrm{~g})$ & 0.84 & - & 136.92 & 136.92 & 548 \\
\hline
\end{tabular}

Total heat per gram of butanol desorbed by thermal desorption:

14,127

1. Sensible heat for heating water from 37 to $125^{\circ} \mathrm{C}$ and butanol and AC from 37 to $200{ }^{\circ} \mathrm{C}$.

2. One gram of $\mathrm{AC}$ would adsorb $\sim 0.25 \mathrm{~g}$ butanol (based on $q=0.25 \mathrm{~g} / \mathrm{g}$ ) and $\sim 1.2 \mathrm{~g}$ water (based on $167 \mathrm{~g} / \mathrm{L}$ butanol in the desorbed phase obtained after condensation). Therefore, for each gram of butanol desorbed, $4.8 \mathrm{~g}$ water would also be desorbed from $4 \mathrm{~g} \mathrm{AC}$. 
Table 3. Comparison of $n$-butanol production in ABE fermentation with in situ butanol adsorption by various adsorbents in serum bottles

\begin{tabular}{lccccc}
\hline & Control & Norit ROW 0.8 & L-493 & SD-2 & CBV901 \\
\hline Initial glucose titer (g/L) & 71.5 & 72.5 & 70.5 & 69.0 & 71.0 \\
Final glucose titer (g/L) & 28.5 & 1.2 & 24.5 & 20.4 & 30.1 \\
Butanol titer (g/L) & 11.7 & 4.1 & 4.8 & 5.2 & 4.5 \\
Final pH & 4.85 & 4.60 & 4.25 & 4.39 & 4.56 \\
Total butanol production (g/L) & 11.7 & 21.9 & 14.5 & 15.2 & 11.5 \\
Butanol yield $(\mathrm{g} / \mathrm{g})$ & 0.27 & 0.31 & 0.31 & 0.31 & 0.28 \\
\hline
\end{tabular}

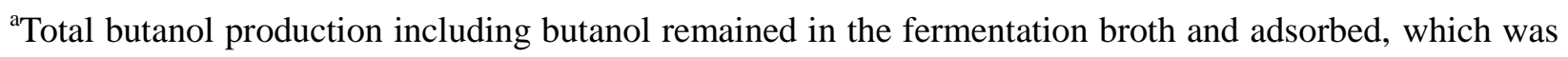
estimated from the final butanol concentration in the fermentation broth and the adsorption isotherm. 
Table 4. Reusability of Norit ROW 0.8 in ABE fermentation with in situ butanol adsorption in serum bottles

\begin{tabular}{lccccc}
\hline & Cycle 1 & Cycle 2 & Cycle 3 & Cycle 4 & Cycle 5 \\
\hline Initial glucose titer (g/L) & 72.5 & 69.0 & 71.0 & 73.5 & 69.0 \\
Final glucose titer (g/L) & 1.2 & 2.6 & 0.6 & 5.2 & 1.0 \\
Final butanol titer in broth (g/L) & 4.1 & 3.5 & 4.8 & 3.3 & 4.9 \\
Amount of butanol adsorbed (g)* & 0.78 & 0.74 & 0.84 & 0.72 & 0.84 \\
Sp. loading (g/g)* & 0.196 & 0.185 & 0.209 & 0.181 & 0.211 \\
\hline
\end{tabular}

*Specific loading was estimated from the final butanol concentration in the broth and the adsorption isotherm (Fig. 2C), and then used to estimate the amount of butanol adsorbed on AC in the fermentation. 
Table 5. Comparison of $n$-butanol production in $\mathrm{ABE}$ fermentation in bioreactor with or without in situ butanol adsorption by activated carbon

\begin{tabular}{lcccc}
\hline & \multicolumn{2}{c}{ Free cell fermentation } & \multicolumn{2}{c}{$\begin{array}{c}\text { Immobilized cell } \\
\text { fermentation }\end{array}$} \\
\cline { 2 - 5 } & $\begin{array}{c}\text { w/o } \\
\text { adsorption }\end{array}$ & $\begin{array}{c}\text { w/ } \\
\text { adsorption }\end{array}$ & $\begin{array}{c}\text { w/o } \\
\text { adsorption }\end{array}$ & $\begin{array}{c}\text { w/ } \\
\text { adsorption }\end{array}$ \\
\hline Fermentation time $(\mathrm{h})$ & 54 & 106 & $47-48$ & 122 \\
Total glucose consumed $(\mathrm{g} / \mathrm{L})$ & 82 & 158 & $76-77$ & 260 \\
Butanol in fermentation broth $(\mathrm{g} / \mathrm{L})$ & 18.3 & 18.7 & $16.0-18.6$ & 8.9 \\
Total amount of butanol adsorbed $(\mathrm{g})$ & - & $18.8-23.5^{\mathrm{a}}$ & - & $53.8-92.2^{\mathrm{b}}$ \\
Butanol removed from fermentation broth $(\mathrm{g} / \mathrm{L})$ & - & $12.9-16.1$ & - & $\sim 45.7$ \\
Total butanol production $(\mathrm{g} / \mathrm{L})$ & 18.3 & $31.6-34.8$ & $16.0-16.6$ & $\sim 54.6$ \\
Butanol yield $(\mathrm{g} / \mathrm{g})$ & 0.22 & $0.20-0.22$ & $0.21-0.22$ & $\sim 0.22$ \\
Butanol productivity $(\mathrm{g} / \mathrm{L} \cdot \mathrm{h})$ & & & & \\
\hline
\end{tabular}

${ }^{a}$ The lower value is based on the total amount of butanol recovered from desorption, while the higher value is based on the assumption that only $80 \%$ of the adsorbed butanol was recovered in desorption.

${ }^{\mathrm{b}}$ The higher value is based on the adsorption isotherm obtained with the pure butanol solution (Fig. 3A) and the lower value is based on the isotherm in the presence of glucose and acetone (Fig. 3C). The actual value should be about the mean of these two values or $73.0 \mathrm{~g} / \mathrm{L}$, which is used in the calculation of total butanol production, yield, and productivity. 
Table 6 Performance summary of different adsorbents during butanol fermentation

\begin{tabular}{|c|c|c|c|c|c|c|c|}
\hline Adsorbent & $\begin{array}{l}\text { Sp. loading } \\
(\mathrm{g} / \mathrm{g})\end{array}$ & $\begin{array}{l}\mathrm{BuOH} \text { in } \\
\text { fermenter } \\
(\mathrm{g} / \mathrm{L})\end{array}$ & $\begin{array}{l}\text { Total } \mathrm{BuOH} \\
\text { production } \\
\quad(\mathrm{g} / \mathrm{L})\end{array}$ & $\begin{array}{c}\mathrm{BuOH} \\
\text { Productivity } \\
(\mathrm{g} / \mathrm{L} \cdot \mathrm{h})\end{array}$ & $\begin{array}{c}\text { BuOH Yield } \\
(\mathrm{g} / \mathrm{g})\end{array}$ & $\begin{array}{c}\mathrm{BuOH} \text { in } \\
\text { desorbed } \\
\text { phase }(\mathrm{g} / \mathrm{L})\end{array}$ & $\begin{array}{l}\text { Reference / } \\
\text { Comments }\end{array}$ \\
\hline Norit W52 & $0.005-0.012$ & $0.7-1.2$ & $0.7-1.4$ & - & - & $5.3-10$ & \multirow{4}{*}{$\begin{array}{l}\text { Groot \& Luyben, } \\
1986\end{array}$} \\
\hline XAD-2 & $0.002-0.030$ & $0.1-4.2$ & $0.3-6.8$ & - & - & $5.4-44$ & \\
\hline XAD-4 & $0.007-0.015$ & $0.3-1.0$ & $1.1-1.7$ & - & - & $15-30$ & \\
\hline XAD-8 & $0.022-0.030$ & $4.7-5.1$ & $7.3-8.6$ & - & - & $29-33$ & \\
\hline \multirow[t]{2}{*}{ PVP } & \multirow[t]{2}{*}{$\sim 0.05$} & 10.5 & 17.5 & $0.31-0.54$ & 0.19 & \multirow[t]{2}{*}{ - } & Yang et al., 1994 \\
\hline & & 16.2 & 27.7 & 0.99 & 0.19 & & Yang \& Tsao, 1995 \\
\hline Dowex SD-2 & $0.26-0.40$ & 3.4 & 22.2 & 0.31 & $0.16-0.24$ & $107-169$ & $\begin{array}{l}\text { Nielsen \& Prather, } \\
2009\end{array}$ \\
\hline Dowex L-493 & $\sim 0.3$ & 12.1 & 27.1 & 0.48 & 0.19 & 85.8 & Wiehn et al., 2014 \\
\hline \multirow[t]{2}{*}{ KA-I } & \multirow[t]{2}{*}{$0.084-0.093$} & \multirow[t]{2}{*}{$>6.5$} & $38.2-58.3$ & $0.67-0.91$ & $0.19-0.20$ & \multirow[t]{2}{*}{-} & Liu et al., 2014 \\
\hline & & & 92.6 & 0.69 & 0.25 & & MV addition \\
\hline Norit ROW0.8 & 0.25 & 8.9 & 54.6 & 0.45 & 0.22 & 167 & This work \\
\hline
\end{tabular}

KA-I: Cross-linked polystyrene diethylbenzene; PVP: Polyvinylpyridine; -: Data not available 


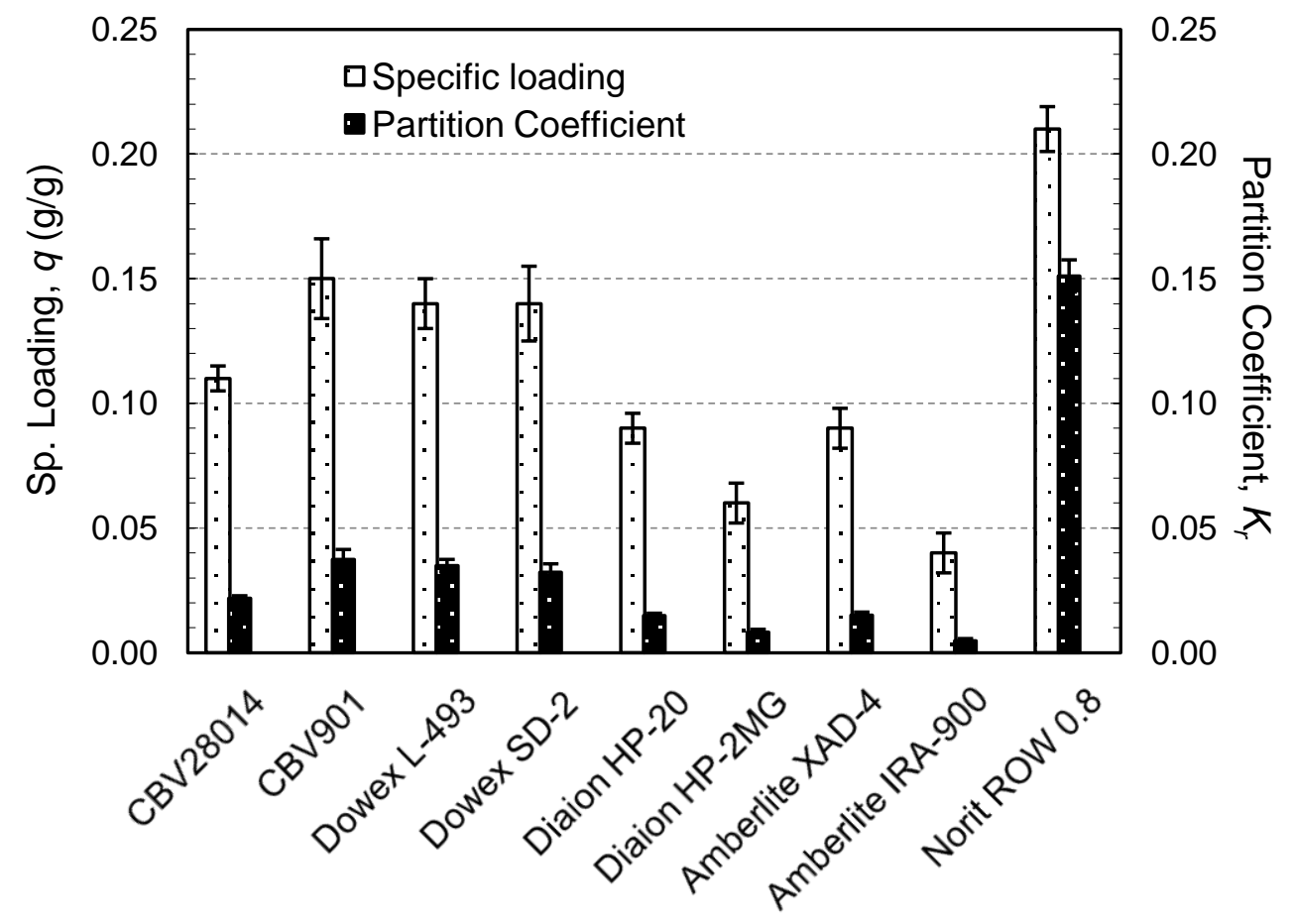

Figure 1 


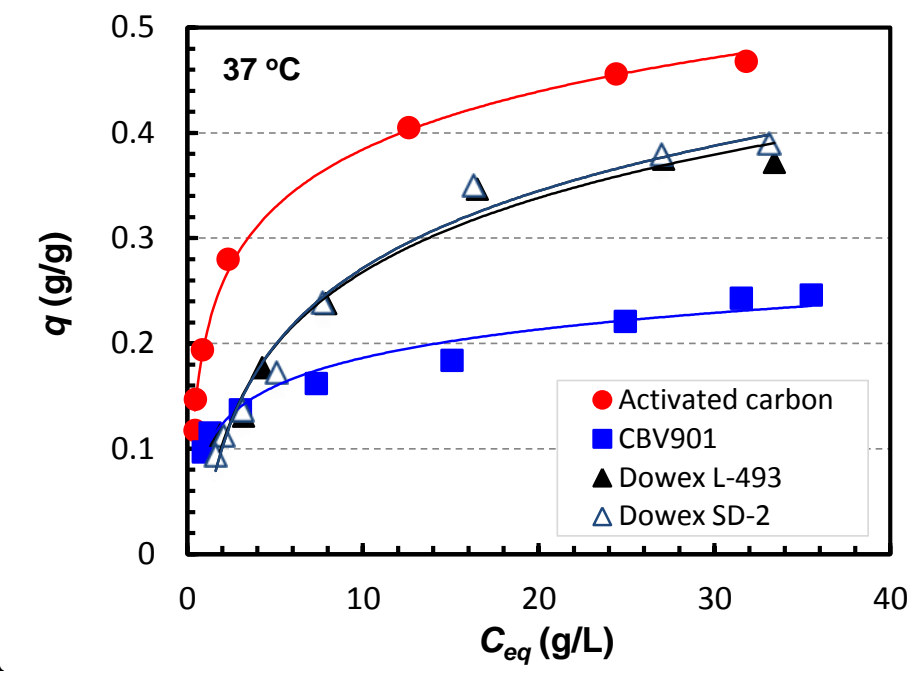

A

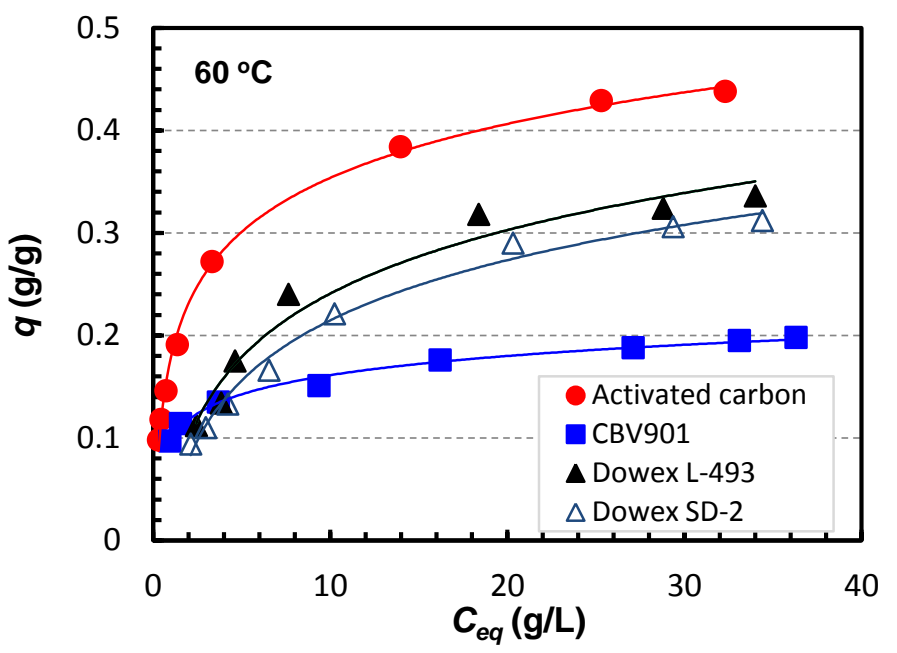

B

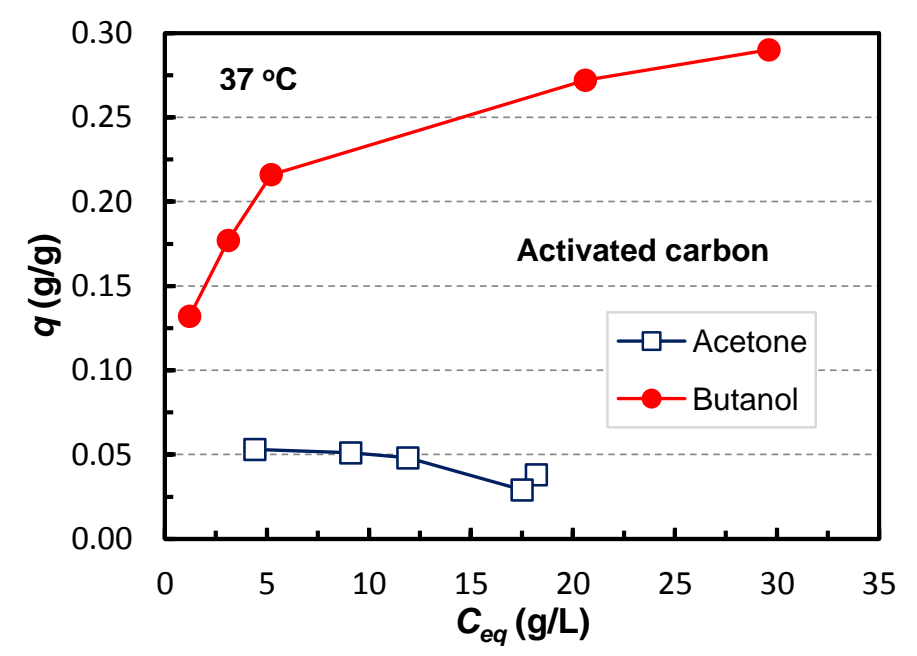

Figure 2 

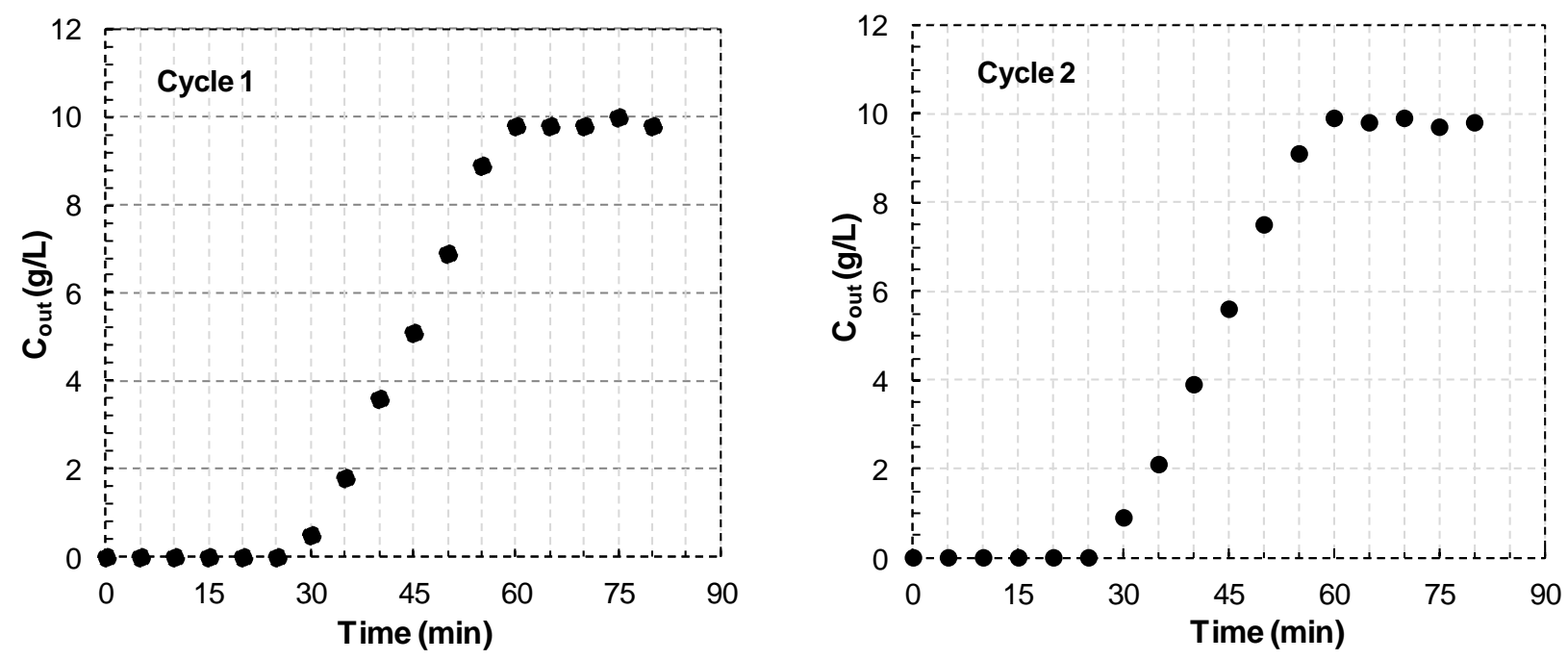

\section{A}

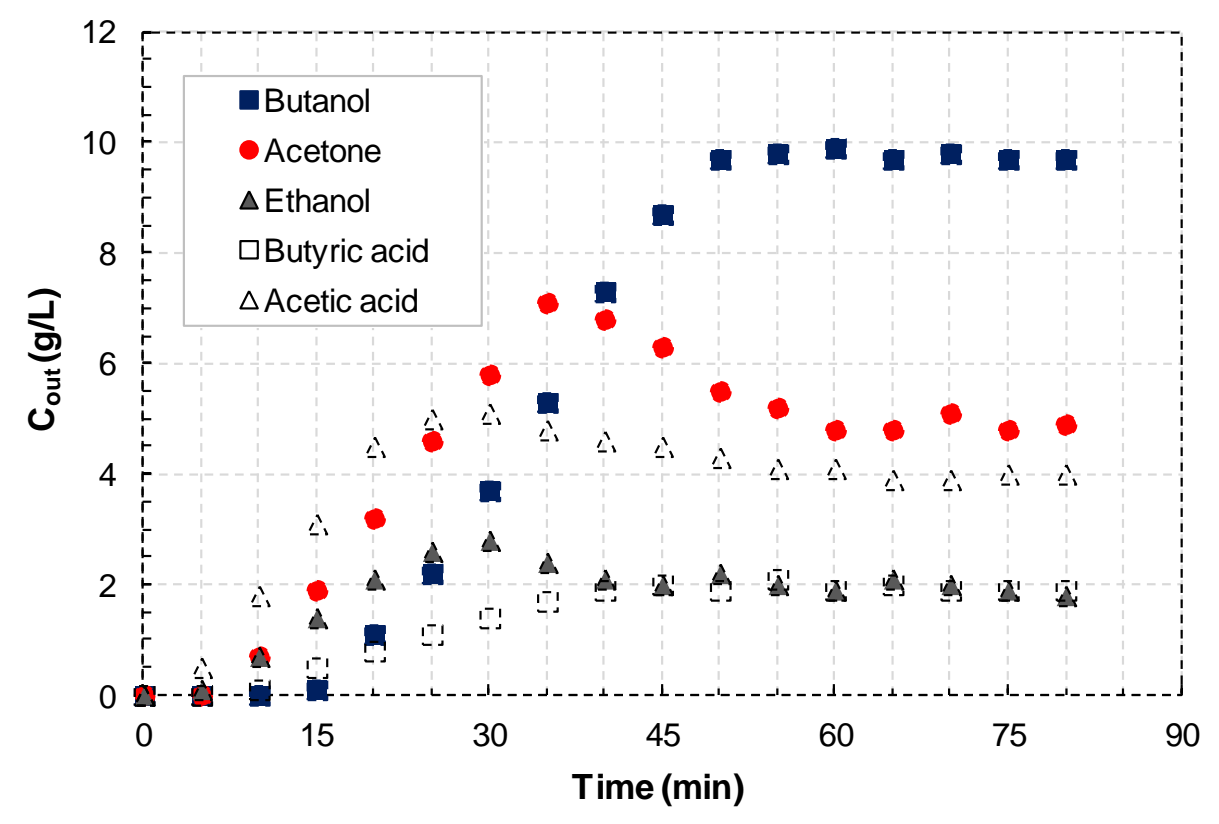

Figure 3 


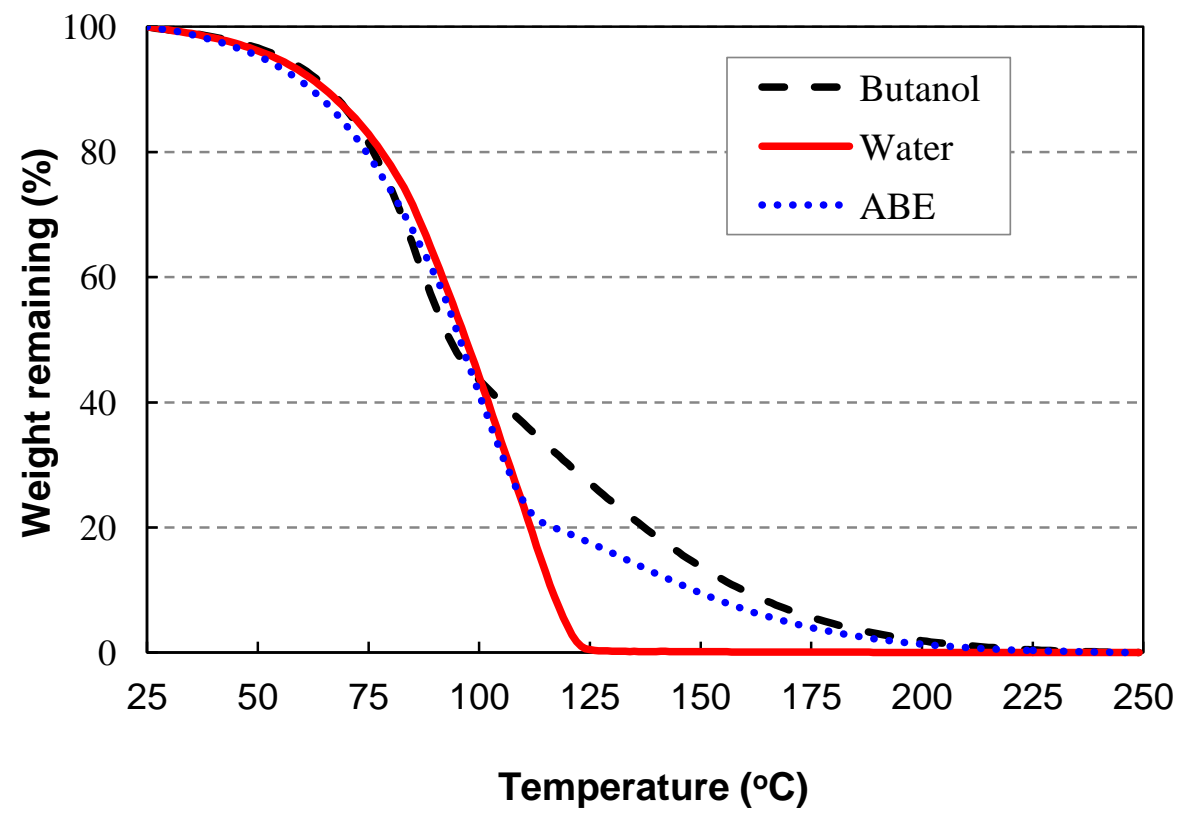

Figure 4 


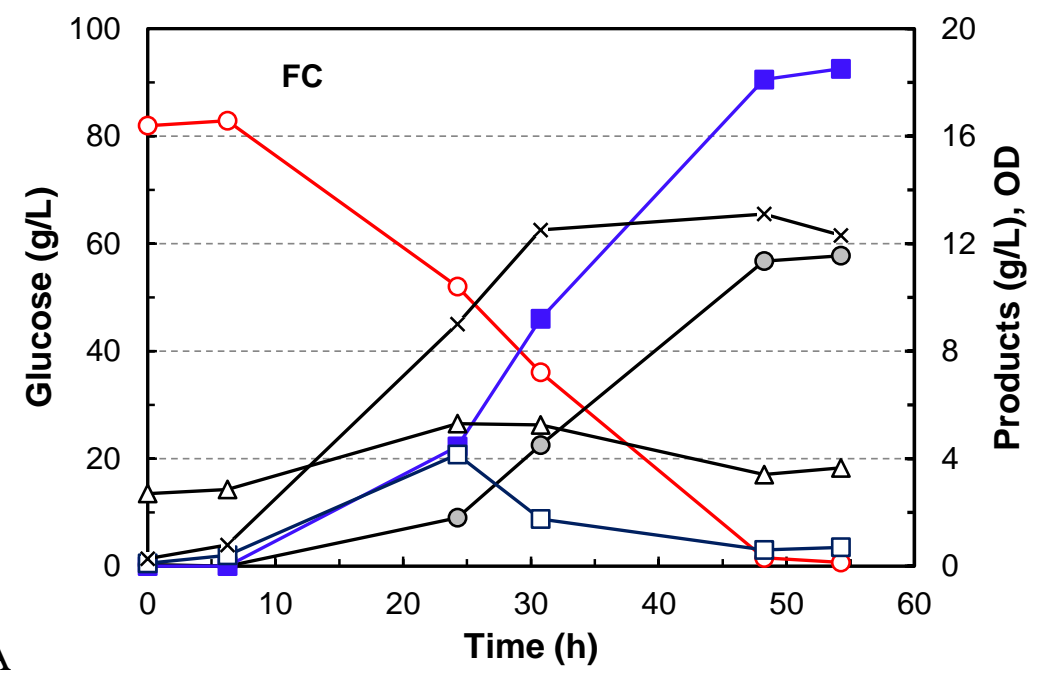

A

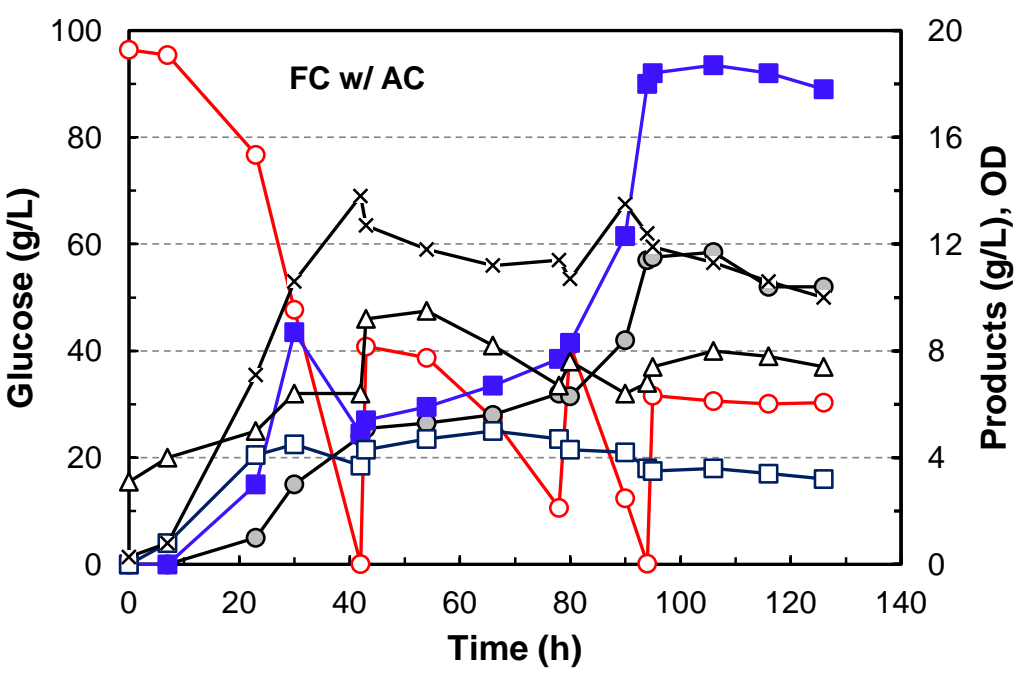

B

$-O-$ Glucose $-\circ-$ Acetone $-\square-$ Butanol $-\triangle$ Acetic acid $-\square-$ Butyric acid $-X-$ O.D.

Figure 5 


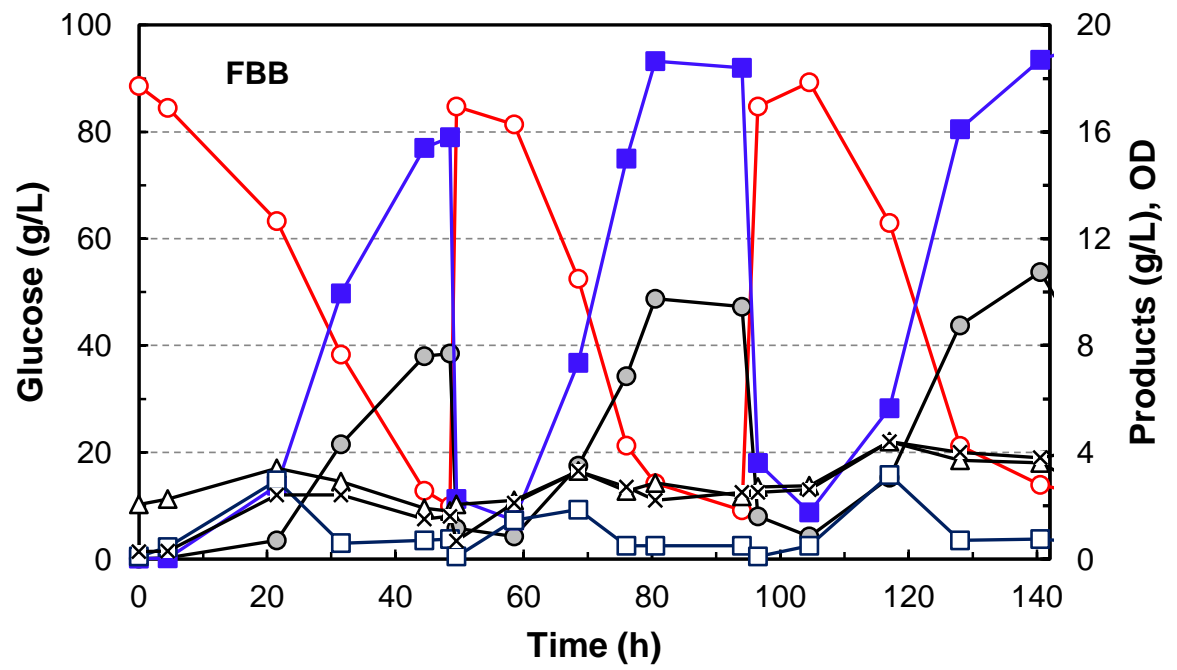

A

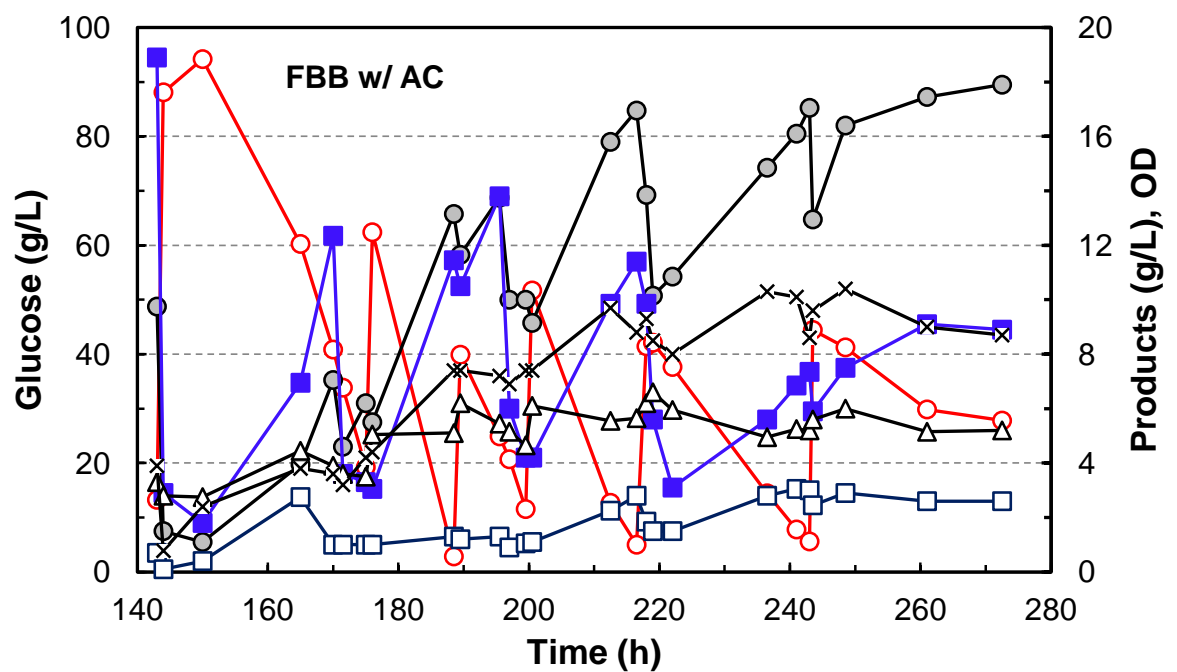

$-\circ$ - Glucose $-\circ$-Acetone - - Butanol $-\triangle$ Acetic acid $-\square$ - Butyric acid $-X-$ O.D.

Figure 6 


\section{Graphical Abstract}

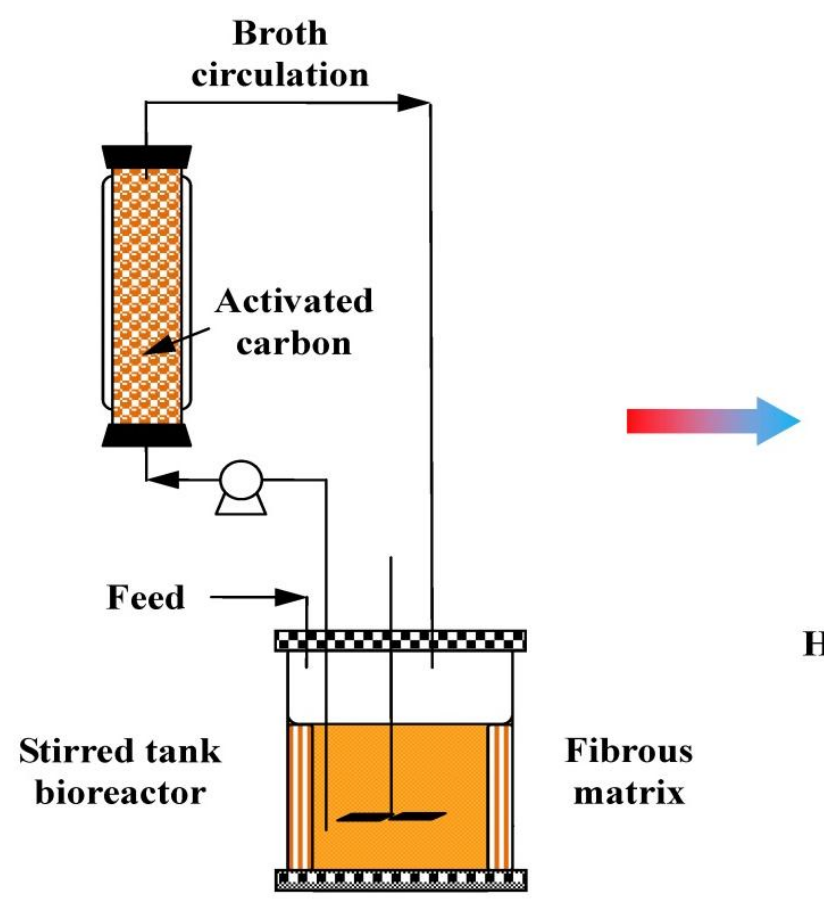

Fermentation with adsorption

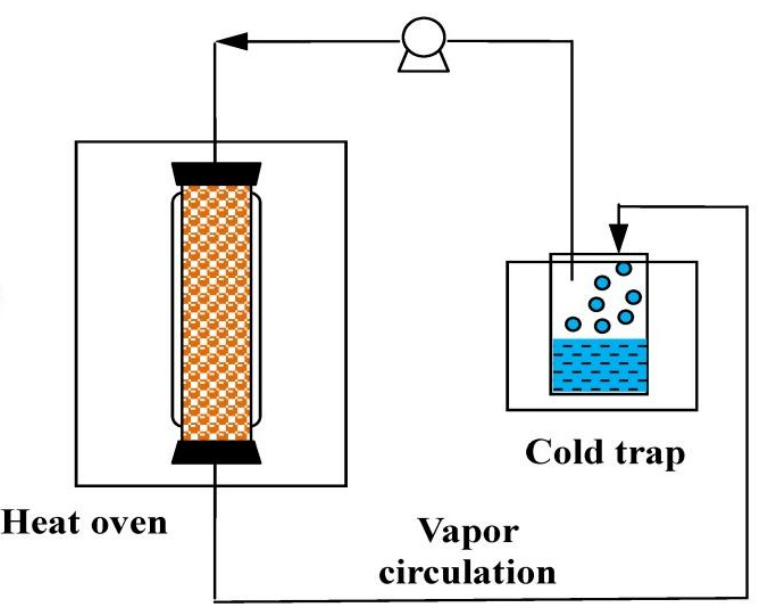

Desorption by heat treatment

An energy efficient process was developed for butanol production in acetone-butanol-ethanol fermentation with cells immobilized in a fibrous matrix attached to the inside wall of the stirredtank bioreactor and butanol adsorption with activated carbon to alleviate butanol toxicity. 